ARTICLE

\title{
Systematic review and meta-analyses of studies analysing instructions to authors from 1987 to 2017
}

\author{
Mario Malički (iD) ${ }^{1,2,7 凶}$, Ana Jerončić (iD) ${ }^{3,7}$, IJsbrand Jan Aalbersberg (iD) ${ }^{4}$, Lex Bouter (iD) ${ }^{5,6}$ \& Gerben ter Riet (iD ${ }^{1,2}$
}

To gain insight into changes of scholarly journals' recommendations, we conducted a systematic review of studies that analysed journals' Instructions to Authors (ItAs). We summarised results of 153 studies, and meta-analysed how often ItAs addressed: 1) authorship, 2) conflicts of interest, 3) data sharing, 4) ethics approval, 5) funding disclosure, and 6) International Committee of Medical Journal Editors' Uniform Requirements for Manuscripts. For each topic we found large between-study heterogeneity. Here, we show six factors that explained most of that heterogeneity: 1) time (addressing of topics generally increased over time), 2) country (large differences found between countries), 3) database indexation (large differences found between databases), 4) impact factor (topics were more often addressed in highest than in lowest impact factor journals), 5) discipline (topics were more often addressed in Health Sciences than in other disciplines), and 6) sub-discipline (topics were more often addressed in general than in sub-disciplinary journals).

\footnotetext{
${ }^{1}$ Urban Vitality Centre of Expertise, Amsterdam University of Applied Sciences, Amsterdam, The Netherlands. ${ }^{2}$ Amsterdam UMC, University of Amsterdam, Department of Cardiology, Amsterdam, The Netherlands. ${ }^{3}$ Department of Research in Biomedicine and Health, University of Split School of Medicine, Split, Croatia. ${ }^{4}$ Elsevier, Amsterdam, The Netherlands. ${ }^{5}$ Department of Philosophy, Faculty of Humanities, Vrije Universiteit, Amsterdam, The Netherlands. ${ }^{6}$ Amsterdam UMC, Vrije Universiteit, Department of Epidemiology and Statistics, Amsterdam, The Netherlands. ${ }^{7}$ These authors contributed equally: Mario

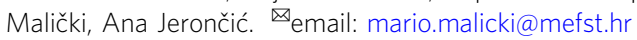


$\mathrm{R}$ eporting of research differs between disciplines, and within journals of the same (sub)discipline, on the format and the structure of the manuscript, as well as on the level of detail with which the research is described ${ }^{1-8}$. Instructions to Authors (ItAs) are documents used by journals to describe specific requirements or recommendations authors should follow when reporting research and submitting their manuscript. Additionally, ItAs can describe the type of checks and review processes a journal employs in evaluating received submissions, and how authors or readers can address (suspected) irregularities in published papers ${ }^{9-12}$. ItAs can also be used to promote or raise awareness of standards ${ }^{13-16}$, and to depict methods aimed at reducing detrimental research practices, research waste, and the inability to replicate published research ${ }^{17-19}$.

Despite 350 years of scholarly publishing, and the existence of $>43,000$ scholarly journals ${ }^{20}$, research on ItAs, and on their evolution and change, is scarce. While it is common practice that journals update their ItAs, the breadth and the extent of changes to ItAs and their variability across disciplines have never been assessed, nor have the insights those changes or differences may provide about the history of scholarly publishing and the development of (best) reporting practices.

Therefore, we synthesised the findings of all studies that have analysed ItAs of more than one journal. After conducting a systematic review, we identified many factors associated with the percentage of ItAs addressing specific topics. Owing to discrepant findings across primary studies, we also conducted a series of meta-analysis to resolve those discrepancies. We focused on the ItAs' recommendations regarding six research integrity topics: authorship, conflicts of interest, data sharing, ethics approval, funding disclosure, and International Committee of Medical Journal Editors Uniform Requirements for Manuscripts (URM).

In this work we summarise 153 studies that analysed ItAs from 1987 to 2017, and we showcase the timeline of ItA changes. We also provide evidence for six factors that explain a substantial part of the wide heterogeneity we found between journals' coverage of the above-mentioned research integrity topics. Those six factors are: (1) time (year when the instructions were applicable), (2) country (in which the journals were published), (3) database (in which the journals were indexed), (4) impact factor, (5) scholarly discipline, and (6) sub-discipline.

\section{Results}

Study selection and characteristics. We identified 153 studies eligible for synthesis of results (Fig. 1 - PRISMA Flow Diagram $)^{21-173}$. Study characteristics are shown in detail in Table 1. These studies were published over a thirty-year period (1987 to 2017) with an observed sharp rise in the number of studies following the year 2002 (and that growth was faster than for all articles published in that period, chi-squared tests, $p<0.0001$ for all comparisons, Fig. 2).

ItAs' contents across these 153 studies were analysed for recommendations or requirements regarding more than a 100 different topics (extracted topics are available in our raw data file) ${ }^{174}$. We grouped those topics into 32 major topics (Table 2), of which the most commonly analysed were Research ethics (i.e., addressing of ethics approvals for conducting studies on humans or animals, $n=53,34 \%$ ), and Reporting guidelines (i.e., recommendations on items that should be reported for specific research studies, $n=51,33 \%)$. The median number of major topics analysed per study was 2 (IQR 1-3). In almost half of the studies $(n=73,48 \%)$ researchers also analysed if addressing of a topic was associated with one or more factors, with a total of 15 different factors explored across studies (Supplementary Table 1).
Narrative synthesis. We identified 12 different primary objectives authors listed for analysing ItAs (Supplementary Table 2), of which the most common were: (1) to determine if and how a specific topic was addressed in ItAs $(n=54,35 \%)$; (2) to determine the reporting or citing of a specific topic in published papers and how the topic was addressed in ItAs $(n=51,33 \%)$; (3) to recommend standards for a specific topic $(n=11,7 \%)$.

Changes over time were analysed in 11 studies $^{23,25,26,31,39,43,59-61,67,75,85,91,103,115,134,141,162}$, covering a time span from 3 to 11 years. Overall, these studies showed that topic coverage increased over time, most notably for: (a) depositing of DNA, amino acid sequence or protein structure data; (b) describing the peer review process; or c) recommending the use of Consolidated Standards of Reporting Trials (CONSORT) Guidelines (Supplementary Table 3).

Differences in reporting of topics in published papers between journals which covered those topics in their ItAs and journals that did not (or at the time when the topics were not addressed) were explored in 17 studies. These mostly showed that reporting is better in journals that covered the topics, albeit suboptimal (i.e., reported in $<80 \%$ of articles, Supplementary Table 4 ). Suboptimal adherence to ItAs was also found in 12 studies which analysed if published papers adhered to requirements stated in ItAs (Supplementary Table 5).

Series of meta-analyses. We conducted meta-analyses for prevalence of journals covering six research integrity topics: authorship, conflicts of interest, data sharing, ethics approval, funding disclosure, and URM. We chose these six topics due to our interest in research integrity, the project's feasibility, and the number of studies that analysed these topics among the 153 identified studies (Table 1). Reported percentages of journals that covered these topics (with percentages being calculated by dividing the number of journals whose ItAs addressed a topic by the total number of journals whose ItAs were analysed in a particular study) for each individual study are available in our raw data file ${ }^{174}$. For each topic, we found large between-study heterogeneity (i.e., wide ranges of reported percentages, journal sample sizes, and journal selection methods); and in the series of meta-analyses we conducted (see Supplementary Section 2), we found strong effects of 6 factors that explained a substantial part of that heterogeneity, namely: (1) time, (2) country, (3) database indexation, (4) impact factor, (5) discipline, and (6) subdiscipline. However, as more than two-thirds of studies analysed ItAs of Health Sciences journals, these studies dominated the collective evidence. All confirmed effects in the meta-analyses, alongside associations that were reported in individual studies, but which could not be meta-analysed due to how data was reported, are presented in Table 3. Summary results for each factor are presented in subsections below. We chose not to report confidence intervals in the subsections below in order to avoid data overload and to allow for descriptive grouping across topics. However, all results per topic, with associated 95\% CIs, are reported in the Supplementary Section 2. Additionally, as time trends were estimated using regression models, percentages reported below may differ from the percentages reported in individual studies.

Time. We found large differences between 1986 and 2016 in percentages of ItAs addressing the six above-mentioned research integrity topics. Overall topic coverage generally increased over time. For example, while in 1995, 40\% of top or Abridged Index Medicus Health Sciences journals addressed authorship and ethics approval, by $2005,>70 \%$ of those journals did so (Fig. 3 and Supplementary Information). In the same period, a similar 


\section{PRISMA PRISMA 2009 Flow Diagram}

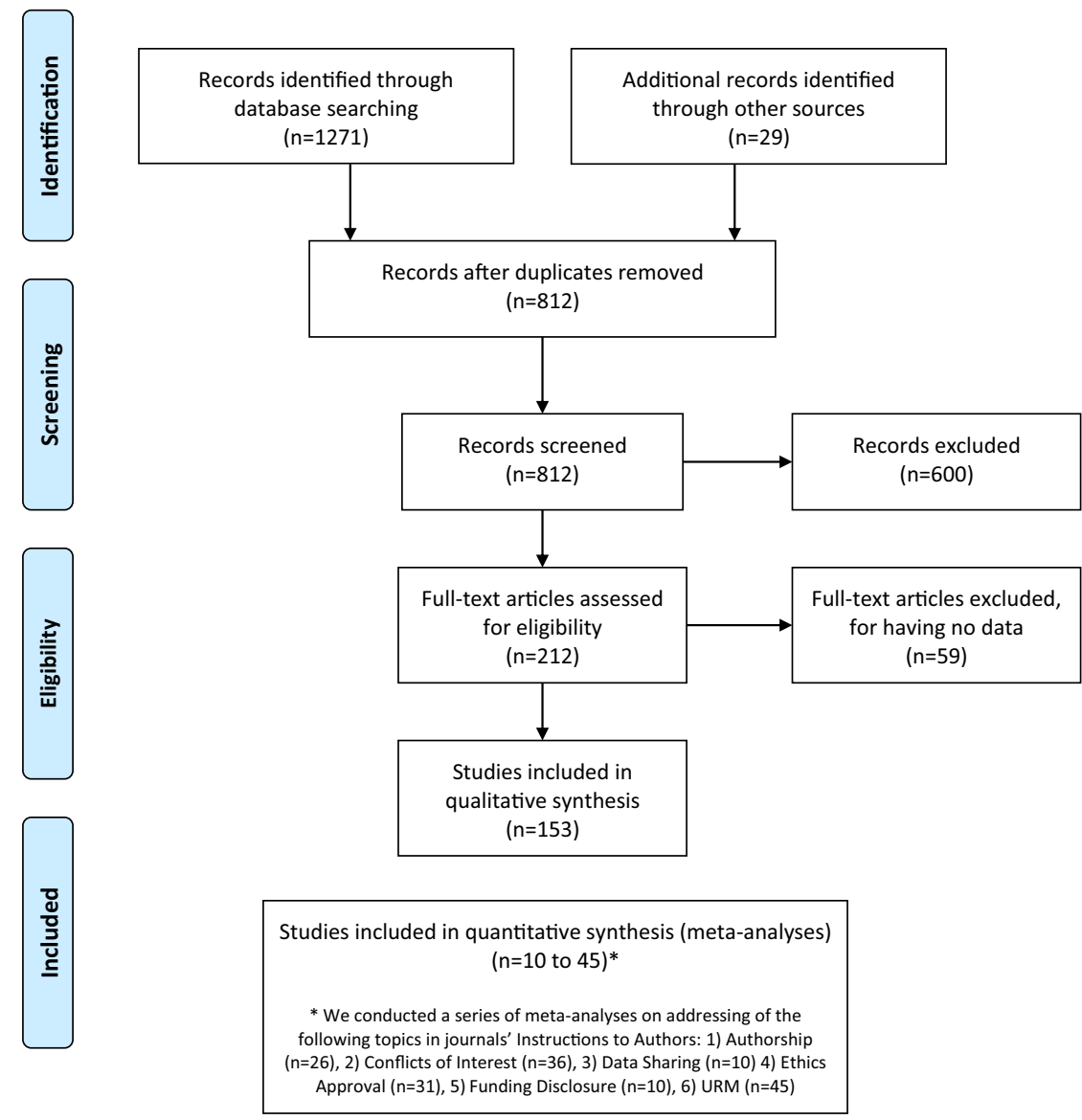

Fig. 1 PRISMA flow diagram. After screening 812 records, we synthesized 153 studies analysing journals' Instructions to Authors (ItAs).

increase was found in UK and USA Health Sciences journals for ethics approval, while Indian and Brazilian Health Sciences journals experienced an increase a decade later (Indian journals, from $57 \%$ in 2004 to $78 \%$ in 2015 , and Brazilian journals, from $56 \%$ in 2007 to $83 \%$ in 2012 ).

An increase over time, however, was not ubiquitous for all topics, (sub)disciplines or countries. In Health Sciences subdisciplinary journals, addressing of conflicts of interest increased from $57 \%$ in 1995 to $87 \%$ in 2015 , but those journals showed no increase after 2000 for URM (60\%), authorship (65\%), or funding disclosure (81\%).

We also observed a decrease in addressing of URM in Abridged Index Medicus Health Sciences journals, from 35\% in 1986 to 5\% in 2006.

Data on changes over time for non-Health Sciences journals was scarce. Top journals (of all disciplines) showed an increase for data sharing (from 15\% in 1992), and for conflicts of interest (from $16 \%$ in 1997), to $>85 \%$ for both topics by the year 2010 (Fig. 3). Additionally, we found an indication of an increase over time for Croatian journals (from all disciplines) for authorship, conflicts of interest, and data sharing from 9\% in 2013 or 2014 to $>20 \%$ in 2015 (Supplementary Information).

Country. We found large differences in addressing of topics between countries. Almost always, topic coverage was lower in journals from a single country than among top or general Health
Sciences journals. For example, while in $2010 \sim 83 \%$ of top journals (of all disciplines) addressed conflicts of interest, in 2014, $89 \%$ of Indian Health Sciences journals did so, and only $9 \%$ of Croatian journals. Similarly, while in 2014 almost $90 \%$ of top Health Sciences journals addressed authorship, 86\% of Chinese journals did so, $70 \%$ of Indian, and $29 \%$ of Croatian journals.

Among Health Sciences journals, addressing of conflicts of interest (89\% in 2014), funding disclosure (70\% in 2008), and URM (75\% in 2014) was most prevalent in Indian journals, ethics approval (86\% in 2005) in UK journals, and authorship (86\% in 2014) in Chinese journals. Chinese journals, however, had the lowest coverage of URM (7\% in 2011).

Country-specific data for journals of all disciplines was only available for Cameroon in 2009, and Croatia for periods 2012 to 2015 , with coverage of all topics found in $<37 \%$ of journals (Supplementary Information).

Journal indexation. Journal indexation was associated with covering of all topics except data sharing (for which no studies provided data for journals from different databases). For example, in 1986, higher percentage of top Health Sciences journals addressed funding disclosure than did Abridged Index Medicus journals ( $47 \%$ vs. $22 \%$, respectively). That situation was reversed for ethics approval 20 years later: with $81 \%$ of Abridged Index Medicus journals in 2006 vs. $71 \%$ of top Health Sciences journals in 2009 (Supplementary Information). Additionally, while Health 


\section{Table 1 Characteristics of studies that analysed Instructions to Authors (ItAs) included in the systematic review, as well as those} meta-analysed per specific topic.

\begin{tabular}{|c|c|c|c|c|c|c|c|}
\hline & \multirow{2}{*}{$\begin{array}{l}\text { Systematic review } \\
(n=153)\end{array}$} & \multicolumn{6}{|c|}{ Meta-analyses } \\
\hline & & $\begin{array}{l}\text { Authorship } \\
(n=26)\end{array}$ & $\begin{array}{l}\text { Conflicts of } \\
\text { interest } \\
(n=36)\end{array}$ & $\begin{array}{l}\text { Data sharing } \\
(n=10)\end{array}$ & $\begin{array}{l}\text { Ethics } \\
\text { approval } \\
(n=31)\end{array}$ & $\begin{array}{l}\text { Funding } \\
\text { disclosure } \\
(n=10)\end{array}$ & $\begin{array}{l}\text { ICMJE URMa } \\
(n=45)\end{array}$ \\
\hline Year of study publications (range) & 1987-2017 & 1999-2017 & 1987-2017 & 1995-2016 & 1997-2017 & 1987-2016 & $1987-2017$ \\
\hline $\begin{array}{l}\text { Year of ItAs that were analysed } \\
\text { (range) }\end{array}$ & 1976-2016 & $1995-2015$ & $1986-2015$ & $1992-2015$ & 1995-2015 & $1976-2015$ & $1986-2016$ \\
\hline $\begin{array}{l}\text { ItAs analysed per publication } \\
\text { (median, range) }\end{array}$ & $56(3-1396)$ & $57(5-445)$ & $54(5-1396)$ & $60(5-850)$ & $65(4-208)$ & $68(6-216)$ & $95(4-747)$ \\
\hline \multicolumn{8}{|l|}{ Discipline analysed $(n, \%)$} \\
\hline Arts and humanities & $0(0)$ & $0(0)$ & $0(0)$ & $0(0)$ & $0(0)$ & $0(0)$ & $38(84)$ \\
\hline Health sciences & $116(76)$ & $18(69)$ & $29(81)$ & $2(20)$ & $26(84)$ & $7(64)$ & $0(0)$ \\
\hline Life sciences & $3(2)$ & $0(0)$ & $0(0)$ & $1(10)$ & $0(0)$ & $0(0)$ & $0(0)$ \\
\hline Multiple & $106(69)$ & $11(42)$ & $19(53)$ & $8(80)$ & $11(35)$ & $6(55)$ & $24(53)$ \\
\hline Brazil & $12(8)$ & $1(4)$ & $4(11)$ & $0(0)$ & $8(26)$ & $1(9)$ & $5(11)$ \\
\hline India & $6(4)$ & $3(12)$ & $2(6)$ & $0(0)$ & $6(19)$ & $1(9)$ & $4(9)$ \\
\hline China & $5(3)$ & $1(4)$ & $1(3)$ & $0(0)$ & $0(0)$ & $0(0)$ & $1(2)$ \\
\hline Croatia & $5(3)$ & $4(15)$ & $2(6)$ & $2(20)$ & $1(3)$ & $1(9)$ & $3(7)$ \\
\hline Spain & $3(2)$ & $1(4)$ & $1(3)$ & $0(0)$ & $0(0)$ & $0(0)$ & $1(2)$ \\
\hline Mexico & $2(1)$ & $0(0)$ & $1(3)$ & $0(0)$ & $0(0)$ & $0(0)$ & $0(0)$ \\
\hline South Korea & $2(1)$ & $0(0)$ & $0(0)$ & $0(0)$ & $1(3)$ & $0(0)$ & $2(4)$ \\
\hline Other (1 per country $)^{b}$ & $12(8)$ & $5(20)$ & $6(17)$ & $0(0)$ & $4(13)$ & $2(18)$ & $5(11)$ \\
\hline \multicolumn{8}{|l|}{ Journal selection methods $(n, \%)$} \\
\hline All journals within a database & $88(57)$ & $23(88)$ & $28(78)$ & $6(60)$ & $25(81)$ & $8(73)$ & $32(71)$ \\
\hline $\begin{array}{l}\text { No. of top journals within a } \\
\text { database }\end{array}$ & $35(23)$ & $0(0)$ & $2(6)$ & $3(30)$ & $1(3)$ & $0(0)$ & $9(20)$ \\
\hline \multicolumn{8}{|l|}{ Analytic method $(n, \%)$} \\
\hline Not specified & $94(61)$ & $12(46)$ & $19(53)$ & $5(50)$ & $21(68)$ & $5(45)$ & $20(44)$ \\
\hline Two independent coders & $32(21)$ & $7(27)$ & $12(33)$ & $1(10)$ & $8(26)$ & $3(27)$ & $15(33)$ \\
\hline One coder & $15(10)$ & $3(11)$ & $1(3)$ & $2(20)$ & $2(6)$ & $2(18)$ & $7(16)$ \\
\hline $\begin{array}{l}\text { One author extracted the data, } \\
\text { the other checked }\end{array}$ & $6(4)$ & $2(8)$ & $1(3)$ & $1(10)$ & $0(0)$ & $0(0)$ & $1(2)$ \\
\hline $\begin{array}{l}\text { One coder extracted data, the } \\
\text { other checked, third checked a } \\
\text { random sample }\end{array}$ & $2(1)$ & $1(4)$ & $1(3)$ & $0(0)$ & $0(0)$ & $1(9)$ & $1(2)$ \\
\hline $\begin{array}{l}\text { Two coders independently } \\
\text { assessed a portion of the } \\
\text { sample, then proceeded } \\
\text { independently to extract from } \\
\text { the remaining journals }\end{array}$ & $2(1)$ & $0(0)$ & $1(3)$ & $0(0)$ & $0(0)$ & $0(0)$ & $0(0)$ \\
\hline $\begin{array}{l}\text { One coder plus help of a text } \\
\text { mining software }\end{array}$ & $1(1)$ & $1(4)$ & $0(0)$ & $1(10)$ & $0(0)$ & $0(0)$ & $0(0)$ \\
\hline $\begin{array}{l}\text { One author extracted sentences } \\
\text { related to the topics analysed, } \\
\text { then two proceeded to code the } \\
\text { extracted sentences }\end{array}$ & $1(1)$ & $0(0)$ & $1(3)$ & $0(0)$ & $0(0)$ & $0(0)$ & $1(2)$ \\
\hline
\end{tabular}




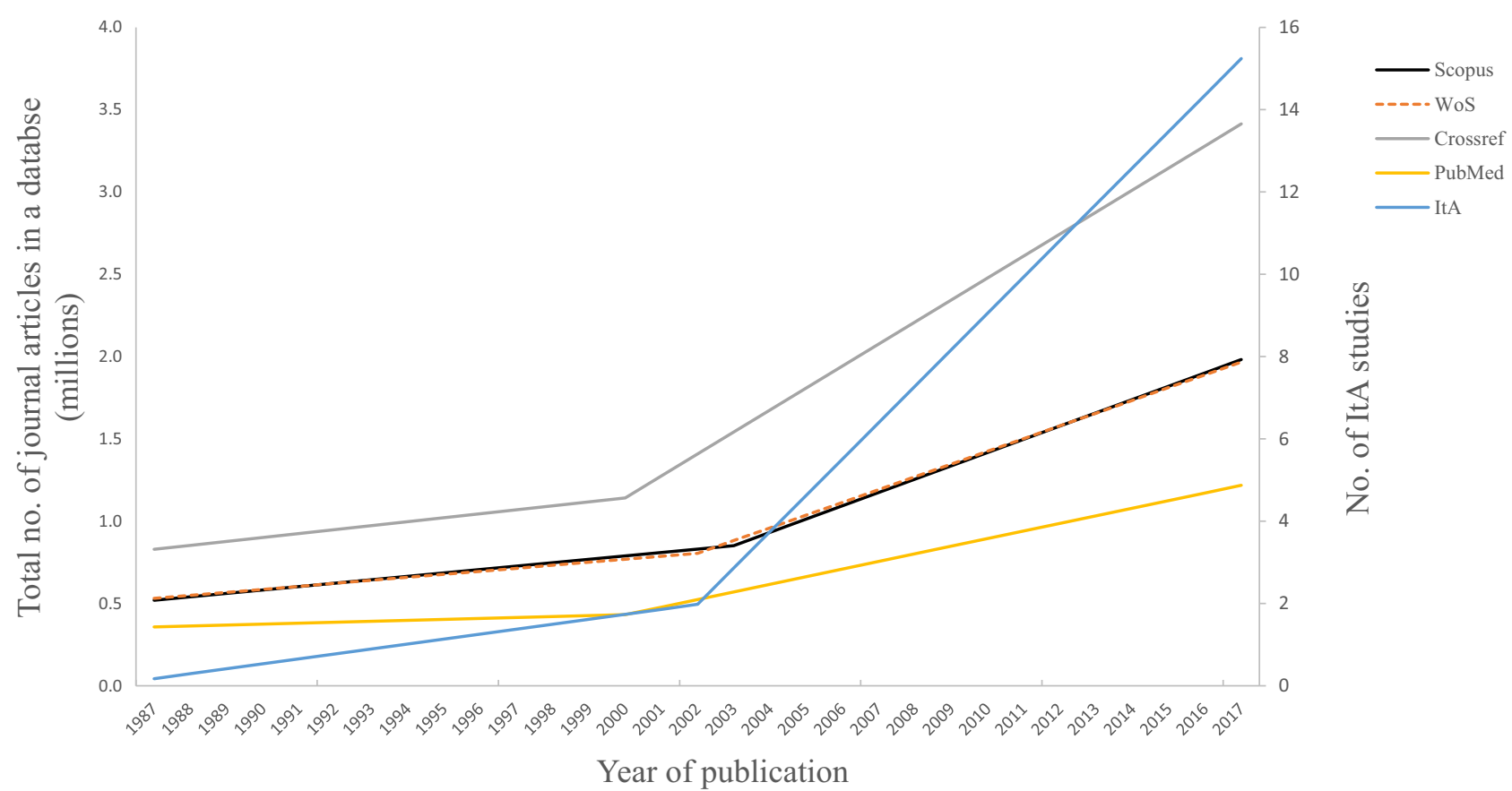

Fig. 2 Growth of the number of publications analysing journals' Instructions to Authors (ItAs). Growth of ItA studies is shown alongside that of journal articles in Crossref, PubMed, Scopus, and Web of Science. Prediction lines were determined by optimal spline regression models.

Table 2 Number of publications analysing a specific topic in journals' Instructions to Authors $(N=153)$.

\begin{tabular}{|c|c|c|c|c|c|}
\hline Topic & $n$ & $\%$ & Topic & $n$ & $\%$ \\
\hline Reporting guidelines & 51 & (33) & Publication of supplementary materials & 6 & (3) \\
\hline ICMJE URM & 44 & (28) & Abbreviations & 5 & (3) \\
\hline Authorship & 35 & $(22)$ & Addressing of sex or ethnicity & 5 & (3) \\
\hline Clinical trial registration & 27 & (17) & Editorial policies & 4 & (2) \\
\hline Publication ethics & 26 & (16) & Journal financial disclosure & 3 & (1) \\
\hline Peer review & 14 & (9) & Registration of systematic reviews & 2 & (1) \\
\hline Referencing & 12 & (7) & Submission format (e.g., email or print) & 2 & (1) \\
\hline Copyright policy & 11 & (7) & Cover letter & 1 & (0) \\
\hline Data sharing & 11 & (7) & Editorial freedom & 1 & (0) \\
\hline Funding disclosure & 10 & (6) & Manuscript limitations & 1 & $(0)$ \\
\hline Statistics & 7 & (4) & Use of medical subject headings & 1 & (0) \\
\hline
\end{tabular}

Sciences journals indexed in Journal Citation Reports (JCR) showed an increase in URM coverage from 2001 (22\%) to 2014 (77\%), Abridged Index Medicus Health Sciences journals showed a decrease between 1986 (37\%) and 2006 (5\%).

For Health Sciences sub-disciplinary journals, almost no differences were found between journals indexed in Directory of Open Access Journals (DOAJ), Index Medicus (IM) or JCR between 2008 and 2016 for URM (60\%), however paediatrics journals index in JCR addressed conflicts of interest (78\%) more often than DOAJ indexed journals (63\%).

Impact factor. We found weak indications that the coverage of authorship, conflicts of interest, and URM was associated with impact factor for Health Sciences sub-disciplinary journals (no data was available for other disciplines, or even for general Health Sciences journals). Specifically, for conflicts of interest, higher coverage was found for $\mathrm{IF} \geq 3$ journals (85\%) compared to journals with IF $<1$ (72\%) between 2008 and 2016, as well as for URM (74\% vs. 50\%). For authorship, higher coverage was found in 2010 for journals with IF values of 1 to 2 (61\%) than for those with IF $<1$ (26\%). Single studies, and studies reporting correlation analyses with IF yielded inconclusive evidence (see additional analyses below and the Supplementary Information).

Discipline. We found large disciplinary differences for all topics, with Health Science journals more often addressing all six research integrity topics (e.g., in 2010 in Web of Science, 59\% of Health Sciences journals addressed authorship vs. 7\% of Arts \& Humanities journals).

However, only 1-3 studies per topic reported disciplinary data, and those were either based on data from 2010 onwards or belonged to country or region-specific disciplinary journals (Croatia, Spain and Latin America, or Spain and the Caribbean, Supplementary Information). 
Table 3 Factors associated with addressing of topics in journals' Instructions to Authors (ItAs). Factors were confirmed by metaregression or by demonstrating significant differences when data were obtained from up to three studies (white background), calculated from data reported in individual studies (green background) or reported as presented in individual studies, i.e., data reported in a way that did not allow calculation (grey background). All associations are presented only descriptively, with full details and $\mathbf{9 5 \%}$ Cls available in the Supplementary Information. We used additional colouring to highlight disciplines (blue), countries (red), and other categories (purple).

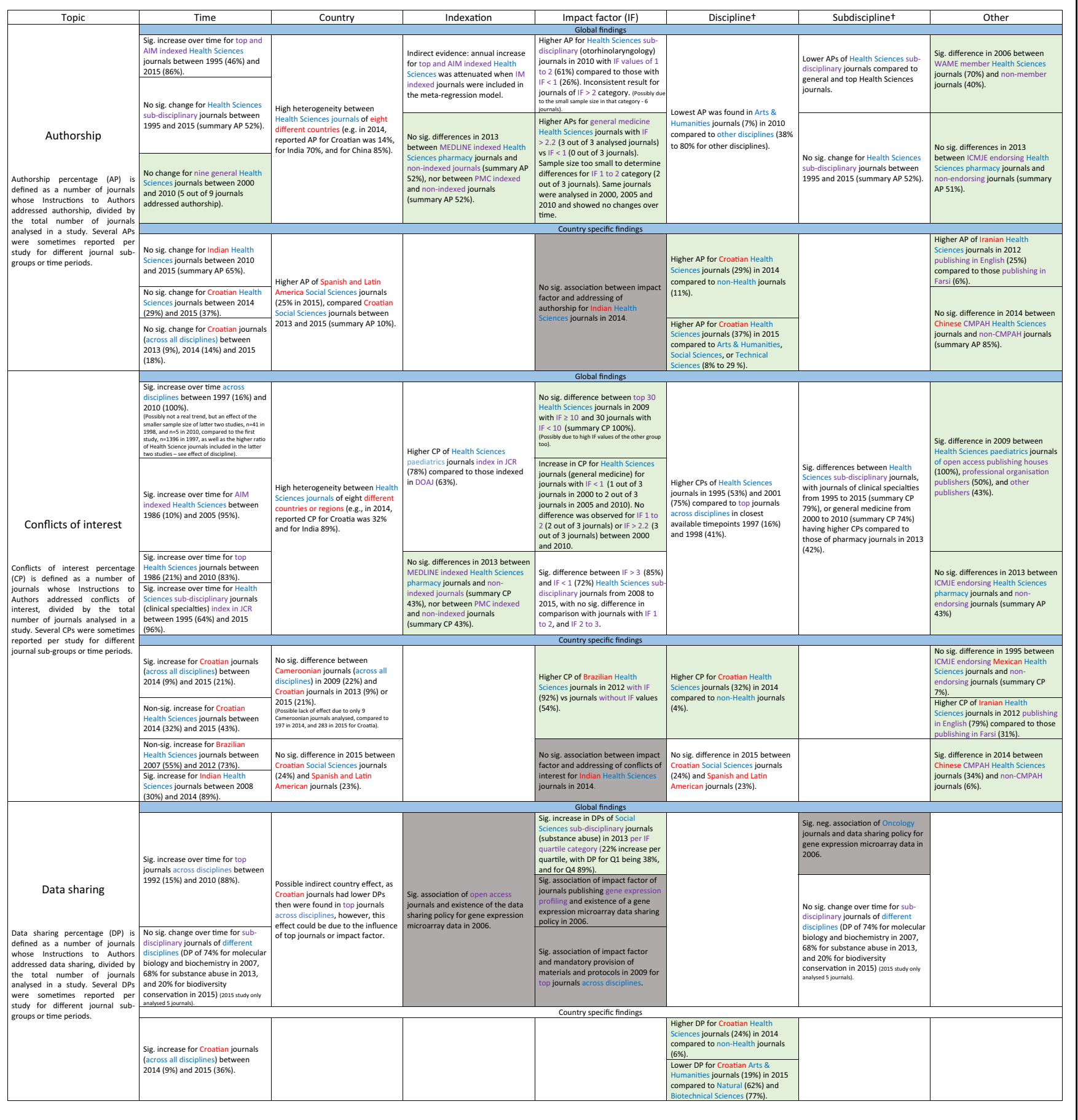

Sub-discipline. Generally, topics were less often addressed in Health Sciences sub-disciplinary than in top or general Health Sciences journals. For authorship, funding disclosure, and URM there were almost no sub-disciplinary differences $(52 \%$ for authorship between 1995 and 2015, 81\% for funding disclosure between 2000 and 2015, and 60\% for URM between 2008 and 2016, Fig. 3). However, we found large differences for ethics approval and conflicts of interest between sub-disciplinary 


\section{Table 3 (continued)}

\begin{tabular}{|c|c|c|c|c|c|c|c|}
\hline Topic & Time & Country & Indexation & Impact factor (IF) & Discipline ${ }^{\dagger}$ & Subdiscipline $^{\dagger}$ & Other \\
\hline \multirow{4}{*}{$\begin{array}{l}\text { Ethics approval percentage (EP) is } \\
\text { defined as a number of journals } \\
\text { whose Instructions to Authors } \\
\text { addressed tethics approval, divided } \\
\text { by the total number of journals } \\
\text { analysed in a study. Several } 1 \text { Es } \\
\text { were sometimes reported per } \\
\text { study for different journal sub- } \\
\text { groups or time periods. }\end{array}$} & $\begin{array}{l}\text { Sig. increase over time for Health } \\
\text { Sciences journals between } 1995 \\
\text { and 2009, with an additional effect } \\
\text { of indexation: higher EP were } \\
\text { found in journals indexed in AIM } \\
\text { (max } 81 \% \text { reached in 2006) } \\
\text { compared to top journals (max of } \\
72 \% \text { reached in 2009). }\end{array}$ & $\begin{array}{l}\text { High heterogeneity between Health } \\
\text { Sciences journals of seven different } \\
\text { countries and two regions (e.g., in } \\
\text { 2012 reportede EP for southeast } \\
\text { European countries was } 41 \% \text { and in } \\
2010 \text { for Brazil } 77 \% \text {. }\end{array}$ & $\begin{array}{l}\text { Higher EP for AIM indexed Health } \\
\text { Sciences journals (max EP of 83\% } \\
\text { reached in 2006) compared to top } \\
\text { journals (max EP of } 71 \% \text { reached in } \\
\text { 2009). }\end{array}$ & \multicolumn{2}{|l|}{ 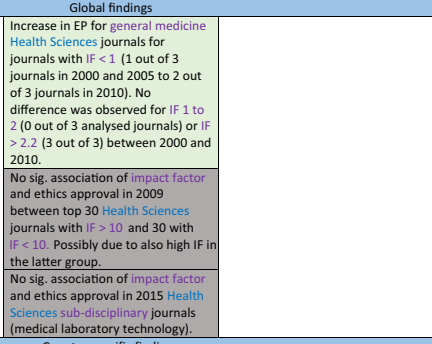 } & 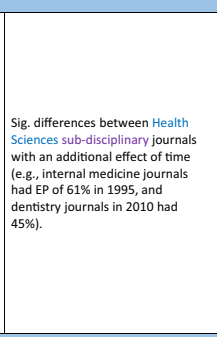 & \\
\hline & $\begin{array}{l}\text { Sig. increase over time for Indian } \\
\text { Health sciences journals between } \\
2004(57 \%) \text { and } 2015 \text { (78\%). }\end{array}$ & No sig. difference between & $\begin{array}{l}\text { Higher EP for ICR indexed Brazilian } \\
\text { Heatth Sciences juornals in } 2012 \\
\text { that had an If value (88\%) } \\
\text { compared to those sampled from } \\
\text { Webqualis/c CAPSES that did not have } \\
\text { an IF value (67\%). }\end{array}$ & \begin{tabular}{|l|}
\multicolumn{2}{|c|}{ Country specific findings } \\
Higher EP for Brazilian Health \\
Sciences journals in 2012 with IF \\
values (88\%) vs journals without If \\
values (67\%).
\end{tabular} & & & $\begin{array}{l}\text { No sig. difference in } 1997 \text { between } \\
\text { South Korean Health cciences } \\
\text { Medical Associatition member } \\
\text { ieurialsand }\end{array}$ \\
\hline & $\begin{array}{l}\text { Sig. increase over time for Brazilian } \\
\text { Health (cciences journals between } \\
2007 \text { (56\%) and } 2012 \text { (83\%). } \\
\end{array}$ & 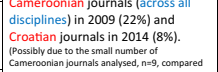 & $\begin{array}{l}\text { No sig. difference in } 2005 \text { and } 2008 \\
\text { between MED UNE indexed Indian }\end{array}$ & \begin{tabular}{|l|} 
Sig. association of impact factor \\
and ethics approval of UK, USA and \\
Canadian Health Sciences journals \\
in 2005 . \\
\end{tabular} & $\begin{array}{l}\text { Higher EP for Croatian Health } \\
\text { Sciences journals (21\%) in } 2014 \\
\text { compared to non-Health journals } \\
\text { (5\%). }\end{array}$ & & $\begin{array}{l}\text { Journiala and quast-member } \\
\text { journals (summary EP of 4\%). }\end{array}$ \\
\hline & 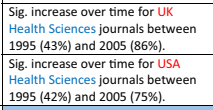 & $\begin{array}{l}\text { to the number of croatian journals analysed, } \\
n=197) .\end{array}$ & 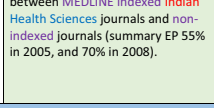 & \begin{tabular}{|l|} 
No sig. association between impact \\
factor and ethics approval for \\
Indian Health Sciences journals in \\
2014. \\
\end{tabular} & & & $\begin{array}{l}\text { Sig. difference in } 2005 \text { and } 2008 \\
\text { between ICMJE endorsing Indian } \\
\text { Health Sciences journals (79\% in } \\
2005 \text { and } 91 \% \text { in 2008) and non- } \\
\text { endorsing journals (41\% in } 2005 \\
\text { and 61\% in 2008). }\end{array}$ \\
\hline Funding disclosure & $\begin{array}{l}\text { No sig. change over time for top } \\
\text { Heatth Sciences journals for } \\
\text { between 1986 and } 1998 \text { (summary } \\
\text { FP of } 47 \% \text { ). } \\
\end{array}$ & 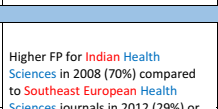 & $\begin{array}{l}\text { Higher FPs in } 1986 \text { for top Health } \\
\text { Sciences journals (40\%) or AlM } \\
\text { indexed journals (22\%) compared } \\
\text { to IM indexed (3\%) or non-indexed } \\
\text { journals }(1 \%) \text {. }\end{array}$ & \begin{tabular}{|l|}
\multicolumn{1}{|c|}{ Global findings } \\
Decrease in FP for Health Sciences \\
journals (general medicine) for \\
journals with IF $<1$ ( 3 out of 3 \\
journals in 2000 and 2005 , to 2 out \\
of 3 journals in 2010). No
\end{tabular} & $\begin{array}{l}\text { Lower FPs for Croatian non-Health } \\
\text { Sciences journals (12\%) and for and } \\
\text { SSaninh and Latin American Social } \\
\text { Sciences journals }(6 \%) \text { compared to }\end{array}$ & $\begin{array}{l}\text { No sig. differences for Health } \\
\text { Sciences sub-discipinary journals } \\
\text { between } 2000 \text { and } 2015 \text { ssummary }\end{array}$ & \\
\hline $\begin{array}{l}\text { is defined as a number of journals } \\
\text { whose Instructions to Authors } \\
\text { addressed funding disclosure, } \\
\text { divided by the total number of }\end{array}$ & 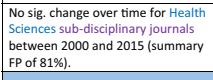 & $\begin{array}{l}\text { Sciences journals in 20121299\%) or } \\
\text { to croatian Health Sciences } \\
\text { journals in } 2014 \text { (37\%). }\end{array}$ & $\begin{array}{l}\text { Higher FP for top Health Sciences } \\
\text { (summary FP 47\% between 1986 } \\
\text { and } 19989 \text { compared to AIM } \\
\text { indexed journals (22\% in 1986). }\end{array}$ & $\begin{array}{l}\text { difference was observed for If } 1 \text { to } \\
2 \text { (o out of } 3 \text { journals) or IF }>2.2 \text { (3 } \\
\text { out of } 3 \text { journals) between } 2000 \\
\text { and } 2010 \text {. }\end{array}$ & $\begin{array}{l}\text { FPs of Health Sciences journals } \\
\text { reported in nine studies (28\% to } \\
\text { 93\%). }\end{array}$ & $\begin{array}{l}\text { between } 2000 \text { and } 2015 \text { (summary } \\
\text { FP of } 81 \% \text { ). }\end{array}$ & \\
\hline $\begin{array}{l}\text { journals analysed in a study. } \\
\text { Several FPs were sometimes } \\
\text { repopted per study for different } \\
\text { journal sub-groups or time periods. }\end{array}$ & & & & Country specific findings & $\begin{array}{l}\text { Higher FP for Croatian Health } \\
\text { Sciences journals }(37 \%) \text { in } 2014 \\
\text { compared to non-Health journals } \\
\text { (12\%). }\end{array}$ & & \\
\hline ICMJE's URM & Sig. increase over time for JCR & $\begin{array}{l}\text { No sig. differences between top } 5 \\
\text { Health or Life Sciences journals of }\end{array}$ & $\begin{array}{l}\text { Higher UPs in } 1986 \text { for top Health } \\
\text { Sciences journals }(53 \%) \text { or AIM } \\
\text { indexed journals }(37 \%) \text { compared } \\
\text { to IM indexed (111\%) or non- } \\
\text { indexed journals }(6 \%) \text {. }\end{array}$ & $\begin{array}{l}\text { Sig, difference between Health } \\
\text { Sciences sub-disciplinary journals }\end{array}$ & & & $\begin{array}{l}\text { No sig. difference in } 2001 \text { between } \\
\text { ICMJE endorsing Health Sciences } \\
\text { journalas and CONSSRT endorsing } \\
\text { journals (summary UP of } 71 \% \text { ). }\end{array}$ \\
\hline $\begin{array}{l}\text { International Committee of Medical } \\
\text { Journal Editors (ICMJE) Uniform } \\
\text { Requirements for Manuscripts } \\
\text { Suminitted to Biomedical Journals } \\
\text { (URM) percentage (UP) is defined }\end{array}$ & $\begin{array}{l}\text { indexed Health Sciences journals } \\
\text { between } 2001(26 \%) \text { and } 2014 \\
(76 \%) .\end{array}$ & 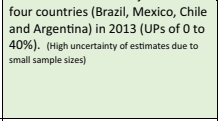 & 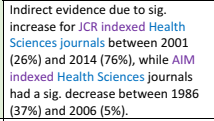 & $\begin{array}{l}\text { with IF } \geq 3 \text { compared to those with } \\
\text { If }<1 \text {. No differences in relation to } \\
\text { middde (II } \geq \geq \text { to } 2 \text { or IF } \geq 2 \text { to } 3 \text { ) } \\
\text { categories. }\end{array}$ & & $\begin{array}{l}\text { Higher UP of top } 15 \mathrm{JCR} \text { indexed } \\
\text { general medicine Health Sciences } \\
\text { journals in 20033 (87\%)/ v ston } 151 \\
\text { clinical specialties journals (22\%). }\end{array}$ & $\begin{array}{l}\text { Sig. difference in } 2003 \text { between } \\
\text { CoNsoRT endorsing Health } \\
\text { Sciences journals (77\%) and non- } \\
\text { endorsing journals }(35 \%) \text {. }\end{array}$ \\
\hline 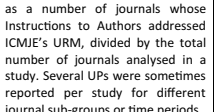 & $\begin{array}{l}\text { sig. decrease over time for AIM } \\
\text { indexed Health Sciconces between } \\
1986(37 \%) \text { and } 2006 \text { (5\%). }\end{array}$ & $\begin{array}{l}\text { High heterogeneity between Health } \\
\text { sciences juourals of different } \\
\text { countries (e.g., in 2011 reported UP } \\
\text { for Chinese journals was } 7 \% \text {, and in } \\
\text { 2012 for Latin American and } \\
\text { Caribbean journals } 61 \% \text {. }\end{array}$ & $\begin{array}{l}\text { No sig. differences for Health } \\
\text { Sciences sub-iliscipinary journals } \\
\text { indexed in DOA, IM or JCR } \\
\text { between } 2000 \text { and } 2016 \text { (summary } \\
\text { UP of } 60 \% \text { ). }\end{array}$ & \begin{tabular}{|l} 
Indirect evidence due to higher UP \\
of top 15 ICR indexed general \\
medicicie Heatlh hciences juornals \\
in 2003 (87\%) vs top 151 clinical \\
specialties journals (22\%). \\
\end{tabular} & & & $\begin{array}{l}\text { No sig. difference in } 2009 \text { between } \\
\text { Heatth Sciences paediatrics juurnals } \\
\text { of open access publishing houses, } \\
\text { professional organisation } \\
\text { publishers or other publishers } \\
\text { (summary UP 65\%). }\end{array}$ \\
\hline journal sub-groups or time periods. & $\begin{array}{l}\text { No sig. differenceses for Health } \\
\text { Sciences sub-disciplinary journals } \\
\text { indexed in DOA, IM or JCR }\end{array}$ & \begin{tabular}{|l|} 
No sig. association with publication \\
country and Health Sciences
\end{tabular} & $\begin{array}{l}\text { Sig. differences in } 2013 \text { between } \\
\text { MELLINE indexed Health sciences } \\
\text { pharmacy journals } 60 \% \text { ) and non- } \\
\text { indexed journals (83\%), with no. }\end{array}$ & $\begin{array}{l}\text { Indirect evidence due to higher UP } \\
\text { of top } 15 \text { Health Sciences journals } \\
\text { in } 1986(53 \%) \text { vs top } 124 \mathrm{JCR}\end{array}$ & & $\begin{array}{l}\text { No sig. differences for Health } \\
\text { Sciences sub-disciplinary journals } \\
\text { indexed in DOA, IM or JCR }\end{array}$ & $\begin{array}{l}\text { No sig. association in } 2010 \text { of } \\
\text { medical association membership or } \\
\text { publication language for eralth } \\
\text { Sciences paediatric journals and } \\
\text { URM. }\end{array}$ \\
\hline & $\begin{array}{l}\text { between } 2008 \text { and } 2016 \text { (summary } \\
\text { up of } 60 \% \text { ). }\end{array}$ & paediatrics journals UPs in 2010 . & $\begin{array}{l}\text { sig. differences between PMC } \\
\text { indexed and non-indexed journals } \\
\text { (summary UP 73\%). }\end{array}$ & $\begin{array}{l}\text { indexed Health Sciences journals in } \\
2001(22 \%) \text {. }\end{array}$ & & $\begin{array}{l}\text { between } 2008 \text { and } 2016 \text { (summary } \\
\text { UP of 60\%). }\end{array}$ & $\begin{array}{l}\text { Sig. differences in } 2013 \text { between } \\
\text { ICMIE endorsing Health Sciences } \\
\text { pharmacy juorrals } 993 \% \text { and non- } \\
\text { endorsing journals (58\%). }\end{array}$ \\
\hline & & & & Country specific findings & & & \\
\hline & $\begin{array}{l}\text { No sig. change over time for } \\
\text { Croatian journals (across all } \\
\text { disciplines) between } 2008(8 \%) \text { and } \\
2013(5 \%) \text {. }\end{array}$ & $\begin{array}{l}\text { Higher UP of Spanish and Latin } \\
\text { American Social Sciences journals }\end{array}$ & $\begin{array}{l}\text { No sig. difference in } 2005 \text { between } \\
\text { MELDINE indexed Indian Heatth } \\
\text { Sciences journals and non-indexed } \\
\text { journals (summary UP 58\%). }\end{array}$ & & $\begin{array}{l}\text { Higher UP of Latin America and } \\
\text { Caribbean Health Sciences journals }\end{array}$ & & $\begin{array}{l}\text { No sig. difference in } 1997 \text { between } \\
\text { South Korean Heath hciences } \\
\text { Medical Association member } \\
\text { journalas and quasi-member } \\
\text { journals (summary UP of } 2 \%) .\end{array}$ \\
\hline & $\begin{array}{l}\text { sig. increase over time for Indian } \\
\text { Health Scciences juornals between } \\
2000 \text { (54\%) and } 2015 \text { (71\%). }\end{array}$ & $\begin{array}{l}115 \%) \text { in } 2015 \text { compared to } \\
\text { Croatian Social Sciences journals in } \\
2013(2 \%) \text {. }\end{array}$ & 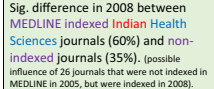 & & $\begin{array}{l}\text { in } 2012 \text { (6161) compared to opanish } \\
\text { and Latin American Social Sciences } \\
\text { journals in } 2015 \text { (15\%). }\end{array}$ & & $\begin{array}{l}\text { Sigg, difference in } 2005 \text { between } \\
\text { IIMJE endorsing Indian Health } \\
\text { Sciences journals }(75 \%) \text { and non- } \\
\text { endorsing journals (49\%). }\end{array}$ \\
\hline
\end{tabular}

${ }^{\star}$ The six disciplines we used in the study are: Arts \& Humanities, Health, Life, Physical, Social, and Multidisciplinary Sciences. The specialties are sub-disciplines found within those areas (e.g., acoustics, botany, history, medicine, etc.).

Abbreviations and acronyms: Abridged Index Medicus (AIM), Chinese Medical Association Publishing House (CMPAH), Consolidated Standards of Reporting Trials (CONSORT), Directory of Open Access Journals (DOAJ), International Committee of Medical Journal Editors (ICMJE), Impact Factor (IF), Index Medicus (IM), Journal Citation Reports (JCR), U.S. National Library of Medicine bibliographic database (MEDLINE), PubMed Central (PMC), World Association of Medical Editors (WAME).

journals of different disciplines (Table 3 and Supplementary Information).

Additional analyses. Individual studies explored the association of seven additional factors with addressing of research integrity topics in ItAs, but again only for Health Sciences journals. The explored factors were language, publishers, endorsement of International Committee of Medical Journal Editors (ICMJE), endorsement of Consolidated Standards of Reporting Trials (CONSORT), membership in World Association of Medical Editors (WAME), in South Korean Medical Association
(SHMA), or Chinese Medical Association Publishing House (CMPAH).

Except for language, for which one study in 2012 reported Iranian journals publishing in English covering authorship and conflicts of interest more often than journals publishing in Farsi ${ }^{112}$, all other explored factors were found to be associated with some topics, while not with others (e.g., more ICMJE endorsing journals addressed ethics approval and URM, but not authorship or conflicts of interest when compared to non-endorsing journals).

Similarly, studies that reported on associations with impact factor values (but without providing data that could be used in 

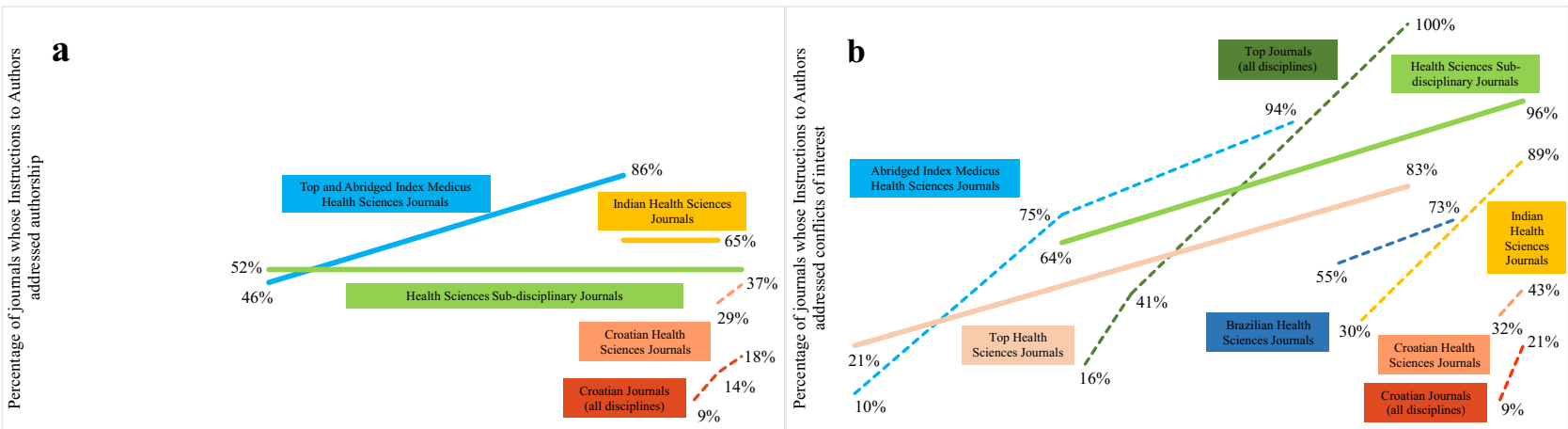

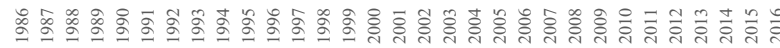
Year

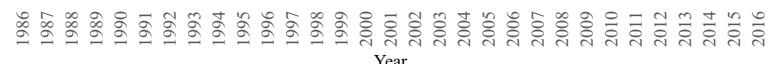

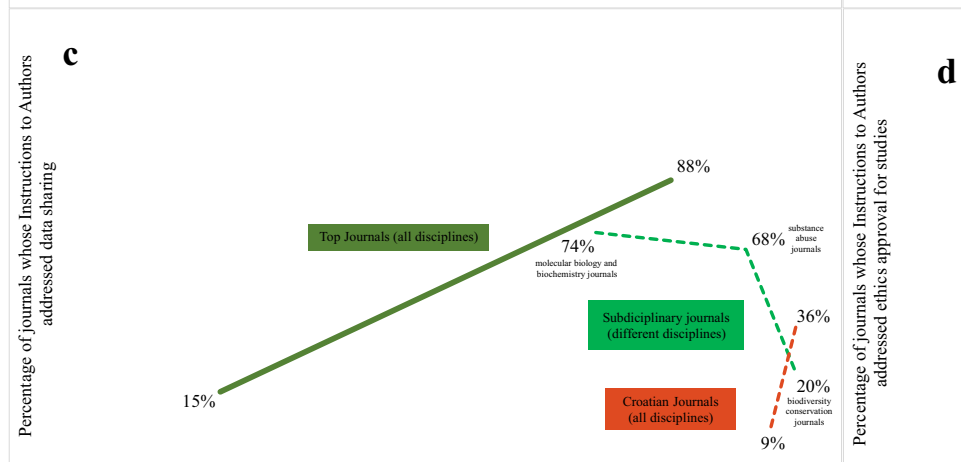

d

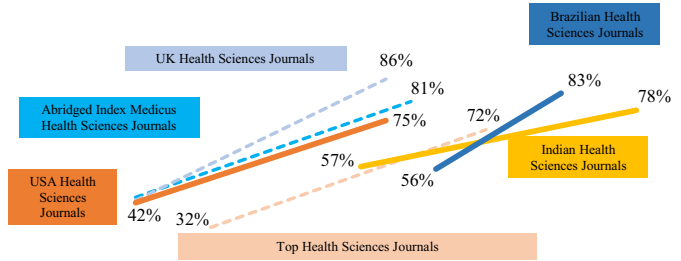

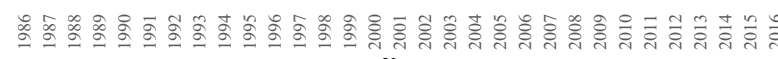
Year

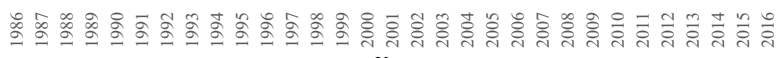
Year
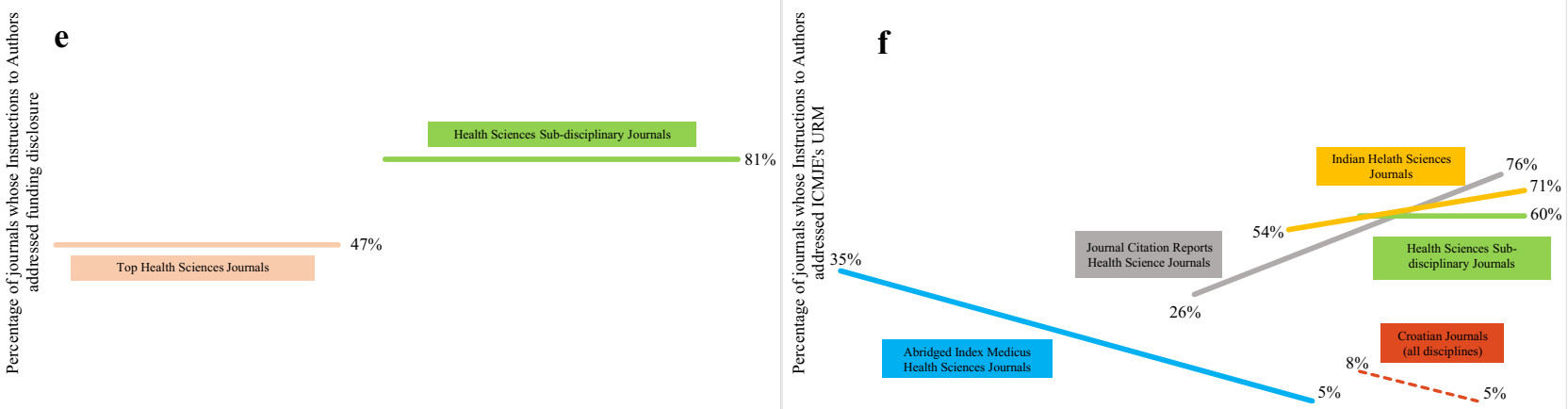

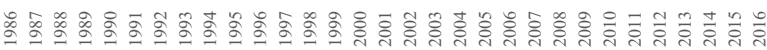
Year

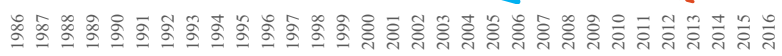
Year

Fig. 3 Changes over time in addressing publication ethics in journals' Instructions to Authors. For ease of comparison all panels are on the same scale, with vertical axes based on a logit scale and percentages added as reference points. Panels represent changes over time for authorship (a), conflicts of interest (b), data sharing (c), ethics approval (d), funding (e), and International Committee of Medical Journal Editors Uniform Requirements for Manuscripts (f). Full lines represent trends obtained through regression models, while dash lines represent percentages reported in up to three studies.

meta-analyses) also reported conflicting results (Table 3 and Supplementary Information).

\section{Discussion}

Our systematic review identified 153 studies that analysed journals' Instruction to Authors (ItAs) and 12 main objectives listed for conducting these studies, of which the most common were to determine whether journals had embraced particular policies or expert recommendations (e.g., reporting of ethics approval), and if papers published in those journals adhere to the journals' requirements. Such interest in journals' ItAs might reflect the attitudes and expectations of researchers that journals and editors should promote best scholarly practices and ensure the highest quality of papers they publish ${ }^{175,176}$. We also found an increase in the number of studies analysing ItAs after 2002, which might reflect the switch to online publishing and the ease of obtaining digital instead of printed versions of ItAs and published papers, as well as the rise in numbers of meta-research studies over the last two decades ${ }^{177}$.

Although there are indications, both in our study, and in the recently published scoping review ${ }^{178}$, that recommendations or requirements stated in ItAs are associated with better study reporting, more studies are needed to identify the best methods for ensuring authors' compliance with ItA's, as well as for conducting editors' and reviewers' checks of that compliance. Future studies could also investigate how often and how well ItAs are read by the authors, and the effect ItAs might have on raising awareness of the topics they address.

Our series of meta-analyses on six research integrity topics (authorship, conflicts of interest, data sharing, ethics approval, 
funding disclosure, and URM) found six factors that were associated with the addressing of those topics in journals' ItAs: time, country, database indexation, impact factor, discipline, and subdiscipline.

The overall increase in the number of journals addressing these topics over the last 30 years may be a results of several factors that include: the improvement of scholarly methods, the progress in teaching of those methods and standards of reporting ${ }^{179,180}$, the rise in (inter)national regulations, especially regulations on obtaining ethics approval for studies ${ }^{181}$, as well as increased attention to research integrity. The fact that most studies analysed ItAs of Health Sciences journals, and that Health Sciences journals covered these topics more frequently than journals of other disciplines, is most likely due to the strict regulations of experimentation on humans and animals, as well as increasing calls in Health Sciences for studies on editorial processes, peer review, research integrity, research waste and replication studies ${ }^{18,175,182-184}$. This could also indicate that Health Sciences journals might be leading the way in reporting practices for journals in other disciplines.

However, while the above findings paint an overall positive picture of the changes in ItAs over the last 30 years for these six research integrity topics, we found many exceptions to those trends. For example, $\sim 52 \%$ of Health Sciences sub-disciplinary journals addressed authorship between 1995 and 2015; and there were also large differences in addressing of research integrity topics between countries (e.g., 14\% of Croatian journals addressed authorship in 2014 vs. $70 \%$ of Indian journals). This indicates that many journals still lag behind recommending, requiring or implementing best reporting practices, which was also confirmed in our recent cross-sectional analysis of 19 transparency in reporting and research integrity topics across disciplines ${ }^{12}$.

Furthermore, while we identified 153 studies that analysed the content of ItAs, the fact that most analysed only specific (sub) samples of journals and looked at addressing of only one or two topics within them, highlights the need for a comprehensive database that would allow authors or other stakeholders to compare journals based on their ItA requirements or recommendations (i.e., akin to SHERPA/RoMEO for listing of journal open-access and self-archiving policies ${ }^{185}$, the Platform for Responsible Editorial Policies ${ }^{186}$ or TOP Factor indicators ${ }^{187}$ ). Such a database could also include indicators of adherence of publications with the journal's requirements. Thus, it could function like Trials Tracker ${ }^{188}$ for monitoring the compliance with EU or FDA regulations on timely posting clinical trial results. It could also enable mapping of changes in ItAs and journals' policies over time, while also providing a quality indicator or reputation safeguard for the journals.

Note that in the meta-analyses we conducted, we found associations for all six factors that we had data for, and that our narrative review showed indications of associations with an additional nine factors. And yet, many other factors potentially associated with the ItAs' contents, like the influence of specific editors or (large) publishers, changes made when a journal reaches a certain level of prestige ${ }^{189}$, or (high profile) misconduct or legal cases, have not been explicitly explored in these studies (the exception being one study which showed differences between open-access publishing houses, professional organisation publishers, and other publishers for addressing of conflict of interest, but not for URM) $)^{90}$.

Finally, both the meta-analyses we conducted and the percentages reported in individual studies on topics we did not metaanalyse, show that different topics follow different patterns, i.e., one topic being addressed in ItAs does not mean another one will be addressed too, nor that its coverage follows the same time trend, and so we warn against generalisation of the patterns we found for the six research integrity topics to other topics.
The strength of our study lies in the fact that we used the systematic review methodology to gather all studies analysing contents of ItAs of more than one journal, rather than focusing on a specific topic(s) or outcomes. But it also has several limitations. First, following our interests and project feasibility, we chose to meta-analyse only topics related to research integrity. Even though these topics were also among the most researched in the studies that analysed ItAs, further research should explore time trends and factors associated with addressing of other topics. Second, previous studies have shown that some enforced practices are not always listed in ItAs ${ }^{190,191}$, while others, including studies listed in our narrative review, that listed practices are not always enforced $^{111,192}$, and finally, that some topics are reported in published papers even if not addressed in ItAs ${ }^{105}$. Afterall, ItAs are not meant to preclude authors for adhering to better reporting, and some authors are likely to go beyond (minimum) requirements imposed by the journals. Third, the association of countries, language and disciplines on reporting of research integrity topics have been demonstrated on a very small number of studies (1-5), of which the strongest indications come from two studies by the same author who looked at the ItAs of Croatian journals ${ }^{143,144}$. So further research into these associations is warranted. Finally, we have summarised information on addressing of topics in ItAs in a binary way (whether or not they were addressed), not on how each individual topic was addressed (e.g., the fact that authorship was addressed in ItAs, does not mean that all journals had the same requirements for authorship, nor that they addressed the number, order of authors, or the practice of shared authorship).

In conclusion, while our findings provide evidence that addressing of these six research integrity topics in journals' ItAs had increased over time, they also showed that many (sub)discipline and regional journals still lag behind in providing such guidance to authors. If publishers, editors and journals want to increase and safeguard the quality and transparency of reporting, they could benefit from updating and implementing policies that reflect and strengthen the integrity of research.

\section{Methods}

We adhered to the Preferred Reporting Items for Systematic Reviews and MetaAnalyses (PRISMA) guidelines ${ }^{193}$.

Protocol and registration. We could not preregister the study in PROSPERO as it did not include any health-related outcome; however, our projects' data repository site contains information on the conception of the study, as well as all the data and notes associated with it ${ }^{174}$

Eligibility criteria. We searched and included all studies that analysed ItAs of more than one journal, irrespective of the topic(s) ItAs were analysed for.

Information sources. We conducted the search on 1 May 2017 in three databases: MEDLINE (through Ovid interface), Scopus, and Web of Science (WoS) with no language or time restrictions. We also searched Google Scholar with the query -allintitle: instructions authors) -, and references of all included studies.

Search. The full search strategy for all three databases is available on our project's data repository site ${ }^{174}$

Study selection. We exported the search results of the three databases into Rayyan software ${ }^{194}$, where manual deduplication was done by MM. Abstracts were assessed independently by MM and AJ to remove irrelevant studies. Disagreed upon studies were obtained in full $(n=25)$. Additional publications were identified through Google Scholar, through searching of references of selected studies, or through authors' awareness of published studies. Full texts of publications were checked by both assessors to confirm the eligibility criteria, and extract topics that were analysed in ItAs and the percentages of journals addressing those topics calculated based on all journals analysed in those studies. 
Data collection process and data items. For each included study, MM extracted the following data in Excel: (1) number of journals whose ItAs were analysed within a study, (2) sampling method for choosing these journals, (3) discipline to which the analysed journals belonged to (reported disciplines were reclassified to fit the following categories: Arts \& Humanities, Health Sciences, Life Sciences, Physical Sciences, Social Sciences, and Multidisciplinary Sciences), (4) sub-discipline to which the journals belonged to (as specified in the respective studies, e.g., dental medicine for Health Sciences), (5) countries or territories in which the journals were published, (6) year when the journals' ItAs were accessed/analysed, (7) topic(s) that were analysed, (8) number and percentage of journals addressing a topic (out of the total number of journals whose ItAs were analysed in a study), (9) method(s) of analysing the ItAs (e.g., one or more researchers reading the ItAs), (10) factors explored for possible association with addressing a particular topic (e.g., journal's impact factor, indexed database, or publisher), and (11) objectives or hypotheses listed as reasons for conducting the study. The (names of) databases in which the journals were indexed were extracted as reported in original studies, we did not assign database indexation to studies in which they were not reported as only a third of studies reported a full list of journals they analysed $(n=53,35 \%$, see below). For all included studies $\mathrm{AJ}$ then checked if the data extraction was done correctly.

Additionally, the following variables were also extracted, but were not included in the results synthesis: (1) if the authors also surveyed editors about questions relating to the submission process, (2) if the studies included a detailed list of journals whose ItAs were analysed.

The data extraction process revealed that $>100$ different topics were analysed across the studies, and so we grouped them into major topic variable, while we also kept a record when studies included other (sub)topics for which we did not extract the data (all recorded sub-topics are available at our project's data repository site) ${ }^{174}$. To clarify, we list here two examples of sub-topics: (1) for the topic Reporting Guidelines, the sub-topics were: mentioning of different specific reporting guidelines; (2) for the topic Case Reports (mentioning of publishing case report studies in the journal), the sub-topics were: maximum word count allowed or requiring a structured abstract.

Finally, on 4 December 2020, we extracted the number of journal articles in PubMed, WoS, Scopus and Crossref. Searches and extracted numbers are available on our project's data repository site ${ }^{174}$.

Synthesis of results and additional analysis. No meta-analyses were predefined at the study conception stage, as the number of topics analysed and the factors explored as determinants of journals addressing a topic could only be assessed after conducting the systematic review.

To study the time trend in the number of studies analysing ItAs and the number of journal publications in PubMed, WoS, Scopus and Crossref, we used a spline regression model that was fitted to the data using nonlinear regression within the SPSS v24 software (IBM, Chicago, IL, USA). Comparisons of number of published studies analysing ItAs published $\leq 2002$ vs. $>2002$, with number of articles published in PubMed, WoS, Scopus, or Crossref in the same period were conducted with a series of chi-squared tests.

Meta-analyses of percentages of journals addressing a particular research integrity topic in ItAs were performed using Comprehensive Meta-analysis Software (CMA) version 3 (Biostat Inc., Englewood, USA), which pools percentages using the logit transformation method. The percentages with their $95 \%$ confidence intervals (CI) were calculated within CMA software from the number of journals addressing a topic out of the total number of journals analysed in a particular study. If percentages reported in a study were $0 \%$ or $100 \%$, CMA introduced a continuity correction to avoid including studies with standard errors of zero.

Random-effects models were used to estimate summary percentages. However, because estimation of random-effects models with few studies have been shown to be unreliable ${ }^{195}$, if fewer than five studies were included in a meta-analysis we applied a fixed-effect model. Statistical heterogeneity of studies was estimated with both Cochran's Q test, and Higgins's $I^{2}$ test statistic. In case of considerable heterogeneity, we did not pool the data, as listing a summary percentage could be misleading. In those cases, to explain the heterogeneity, we conducted mixedeffects subgroup analyses (for categorical factors such as countries, disciplines, or impact factor categories reported in the studies) or random-effects metaregressions based on the DerSimonian and Laird method, which doesn't assume that effect sizes are normally distributed (for the factors time, impact factor values, discipline, or indexed database). We also searched for sources of heterogeneity if percentages were dispersed throughout the 0 to $100 \%$ interval, but due to high uncertainty $95 \%$ CIs largely overlapped). If the number of studies was too small to perform meta-regression and a factor was numerical (i.e., for $n<4$ when the factor time was assessed), we decided that a factor significantly affects the percentages if we could show: (a) consistency in direction of change in percentages with growing values of the factor, and (b) significant differences between percentages assigned to neighbouring values of a factor. Differences in percentages reported in two studies, together with associated $95 \%$ CIs for the difference, as well as $p$-values for statistical test of differences, were estimated by Exploratory Software for Confidence Intervals (ECSI) software ${ }^{196}$. Pseudo- $\mathrm{R}^{2}$ index was used to quantify the proportion of variance explained by a factor.
A $p$-value of $<0.05$ was considered to indicate statistical significance. However, when analyses were underpowered (e.g., for comparison of two estimates with one being made on a sample of five journals), we also stated if a result was significant at the 0.1 level. All the tests were two-sided.

Risk of bias. We are aware of no tools that measure the risk of bias of studies whose units of analysis are ItAs. As the methodology of these studies involves selecting journals for analysis, obtaining ItAs from printed volumes or downloading them from journal's websites, and extracting data on topics addressed in ItAs by reading them (by one or more researchers) or using qualitative text analysis software, we included all eligible studies in synthesis of results and meta-analyses. We, however, did provide notes, in both Table 3 and the Supplementary Section 2 about methodological factors, which could have an effect on the validity and reliability of reported estimates. In regards to selection bias, none of the studies used probability sampling that would cover all disciplines and a wide range of journal (citation) influences or indexing databases. Rather, most studies analysed ItAs of Health Sciences journals $(n=116,76 \%)$, and sampled only journals that were indexed in the Journal Citation Reports database $(n=55,47 \%)$. In regards to reporting bias, studies often omitted explaining their methods of analysing ItAs $(n=94,61 \%)$, or listing the year of ItAs that were analysed $(n=69,45 \%$, Table 1$)$.

\section{Data availability}

The data generated in this study have been deposited in the Mendeley repository with the identifier: https://data.mendeley.com/datasets/53cskwwpdn/5 174 .

Received: 11 May 2020; Accepted: 24 August 2021; Published online: 05 October 2021

\section{References}

1. Stevens, A. et al. Relation of completeness of reporting of health research to journals' endorsement of reporting guidelines: systematic review. BMJ 348, g3804 (2014).

2. Leung, V., Rousseau-Blass, F., Beauchamp, G. \& Pang, D. S. ARRIVE has not ARRIVEd: support for the ARRIVE (Animal Research: Reporting of in vivo Experiments) guidelines does not improve the reporting quality of papers in animal welfare, analgesia or anesthesia. PLOS ONE 13, e0197882 (2018).

3. Chhapola, V., Tiwari, S., Brar, R. \& Kanwal, S. K. Reporting quality of trial abstracts-improved yet suboptimal: a systematic review and meta-analysis. J. Evid.-Based Med. 11, 89-94 (2018).

4. Alluqmani, A. \& Shamir, L. Writing styles in different scientific disciplines: a data science approach. Scientometrics 115, 1071-85 (2018).

5. Argamon, S., Dodick, J. \& Chase, P. Language use reflects scientific methodology: a corpus-based study of peer-reviewed journal articles. Scientometrics 75, 203-238 (2008).

6. Marusic, A., Bosnjak, L. \& Jeroncic, A. A systematic review of research on the meaning, ethics and practices of authorship across scholarly disciplines. PLoS ONE 6, e23477 (2011)

7. Sollaci, L. B. \& Pereira, M. G. The introduction, methods, results, and discussion (IMRAD) structure: a fifty-year survey. J. Med. Libr. Assoc. 92, 364-367 (2004).

8. Lin, L. \& Evans, S. Structural patterns in empirical research articles: A crossdisciplinary study. Engl. Specif. Purp. 31, 150-160 (2012).

9. Nambiar, R., Tilak, P. \& Cerejo, C. Quality of author guidelines of journals in the biomedical and physical sciences. Learn Publ. 27, 201-206 (2014).

10. Bosch, X., Hernández, C., Pericas, J. M., Doti, P. \& Marušić, A. Misconduct policies in high-impact biomedical journals. PLoS ONE 7, e51928 (2012).

11. Hauptman, P. J., Armbrecht E. S., Chibnall J. T., Guild C., Timm J. P. \& Rich M. W. Errata in medical publications. Am J Med. 127, 779-785 (2014).

12. Malicki, M., Aalbersberg, I. J. J., Bouter, L. \& Ter Riet, G. Journals' instructions to authors: a cross-sectional study across scientific disciplines. PLOS ONE 14, e0222157 (2019).

13. Ceprano, M. A. \& Stabile, C. A comparative study of four reading journals' contributions to comprehension instruction methodology. Lit. Res. Instr. 25, 108-115 (1986).

14. Olson, C. M. \& Jobe, K. A. Reporting institutional review board approval and patient consent. JAMA 278, 477 (1997).

15. Wager, E. \& Williams, P. Project Overcome failure to Publish nEgative fiNdings C. "Hardly worth the effort"? Medical journals' policies and their editors' and publishers' views on trial registration and publication bias: quantitative and qualitative study. BMJ 347, f5248 (2013).

16. Curran, W. J. The law and human experimentation. N. Engl. J. Med. 275, 323-325 (1966)

17. Chalmers, I. \& Glasziou, P. Avoidable waste in the production and reporting of research evidence. Lancet 374, 86-89 (2009). 
18. Pupovac, V. \& Fanelli, D. Scientists admitting to plagiarism: a meta-analysis of surveys. Sci. Eng. Ethics 21, 1331-1352 (2015).

19. Katavic, V. Retractions of scientific publications: responsibility and accountability. Biochem. Med. (Zagreb) 24, 217-222 (2014).

20. Johnson R., Watkinson A. \& Mabe M. The STM Report: an Overview of Scientific and Scholarly Publishing. The International Association of Scientific, Technical and Medical Publishers. 5th edition (2018).

21. Else, J. F. \& Sanford, M. J. Nonsexist language in social work journals: Not a trivial pursuit. Soc. Work 32, 52-59 (1987).

22. Weller, A. C. Editorial policy and the assessment of quality among medical journals. Bull. Med. Libr. Assoc. 75, 310 (1987).

23. Weller, A. C. The "Instructions to Authors" section as an aid in serials collection development. Ser. Librarian 11, 143-154 (1987).

24. McCain, K. W. Mandating sharing: Journal policies in the natural sciences. Sci. Commun. 16, 403-431 (1995).

25. Sosa-de-Martínez, M., Carnevale, A. \& Avendaño-Inestrillas, J. Comparison of instructions to authors of Mexican medical journals and the Vancouver requirements. Rev. Invest. Clin. 47, 203-210 (1995).

26. Amdur, R. J. \& Biddle, C. Institutional review board approval and publication of human research results. JAMA 277, 909-914 (1997).

27. Jeong, I.-S., Baik, J.-M., Jang, I.-J. \& Shin, S.-G. Ethical Guidelines Published in the Instruction for Authors of Biomedical Journals in Korea. Korean J. Clin. Pharm. Ther. 6, 339-343 (1998).

28. Asai, T. \& Shingu, K. Ethical considerations in anaesthesia journals. Anaesthesia 54, 192-197 (1999).

29. Marsh, H. \& Eros, C. M. Ethics of field research: Do journals set the standard? Science and Engineering. Ethics 5, 375-382 (1999).

30. Sardenberg, T., Müller, S., Pereira, H. \& Hossne, W. Analysis of ethical aspects on human experimentation included in the instructions for the authors in 139 Brazilian scientific journals. Rev. da Associacao Med. Brasileira (1992) 45, 295-302 (1999).

31. Sosa-de-Martínez, M. et al. Norms for authors of Mexican medical journals in 1994 and 1995. Rev. Invest. Clin. 51, 235-244 (1999).

32. Tanahashi, Y. Importance of author abstract and comparative analysis of journals' instructions to authors. Inf. Sci. Technol. Assoc. 49, 236-243 (1999).

33. Brown, C. The E-volution of preprints in the scholarly communication of physicists and astronomers. J. Assoc. Inf. Sci. Technol. 52, 187-200 (2001).

34. Krimsky, S. \& Rothenberg, L. S. Conflict of interest policies in science and medical journals: editorial practices and author disclosures. Sci. Eng. Ethics 7, 205-218 (2001).

35. Ferguson, J. A., Mockbee, C., Erbele, S. \& Muniz, E. Evaluation of published case reports' standards and notification. Drug Inf. J. 36, 303-307 (2002).

36. Atlas, M. C. Emerging ethical issues in instructions to authors of high-impact biomedical journals. J. Med. Libr. Assoc. 91, 442 (2003)

37. Bayne, S. C., McGivney, G. P. \& Mazer, S. C. Scientific composition and review of manuscripts for publication in peer-reviewed dental journals. $J$. Prosthet. Dent. 89, 201-218 (2003).

38. Brown, C. The changing face of scientific discourse: Analysis of genomic and proteomic database usage and acceptance. J. Am. Soc. Inf. Sci. Technol. 54, 926-938 (2003).

39. Casserly, M. F. \& Bird, J. E. Web citation availability: analysis and implications for scholarship. Coll. Res. Libraries 64, 300-317 (2003).

40. Scheetz M. D. Promoting Integrity Through "Instructions to Authors" A Preliminary Analysis. https://ori.hhs.gov/sites/default/files/ instructions_authors.pdf (2003).

41. Atlas, M. C. Retraction policies of high-impact biomedical journals. J. Med. Libr. Assoc. 92, 242 (2004).

42. Sorinola, O., Olufowobi, O., Coomarasamy, A. \& Khan, K. S. Instructions to authors for case reporting are limited: a review of a core journal list. $B M C$ Med. Educ. 4, 4 (2004).

43. Altman, D. G. Endorsement of the CONSORT statement by high impact medical journals: survey of instructions for authors. BMJ 330, 1056-1057 (2005).

44. Nakayama, T., Hirai, N., Yamazaki, S. \& Naito, M. Adoption of structured abstracts by general medical journals and format for a structured abstract. $J$. Med. Libr. Assoc. 93, 237 (2005)

45. Shih, Y.-T., Shih, S.-F., Chen, N.-S. \& Chen, C.-S. Human research protections-Current status in Taiwan and policy proposals. Taiwan. J. Public Health 24, 360-373 (2005).

46. Berhidi, A., Geges, J. \& Vasas, L. The biomedical periodicals of Hungarian editions-historical overview. Orv. Hetil. 147, 457-467 (2006).

47. Outram, S. M. \& Ellison, G. T. Improving the use of race and ethnicity in genetic research: a survey of instructions to authors in genetics journals. Sci. Ed. 29, 78-81 (2006)

48. Poolman, R. W. et al. Does a "Level I Evidence" rating imply high quality of reporting in orthopaedic randomised controlled trials? BMC Med. Res. Methodol. 6, 44 (2006)
49. Puhan, M. A., Ter Riet, G., Eichler, K., Steurer, J. \& Bachmann, L. M. More medical journals should inform their contributors about three key principles of graph construction. J. Clin. Epidemiol. 59, 1017-1022 (2006).

50. Schriger, D. L., Arora, S. \& Altman, D. G. The content of medical journal Instructions for authors. Ann. Emerg. Med. 48, 743-749 (2006).

51. Woolley, K. L. et al. Declaration of medical writing assistance in international peer-reviewed publications. JAMA 296, 929-934 (2006).

52. Hartley, J. Clarifying the sub-headings of structured abstracts. Eur. Sci. Editing 33, 41-42 (2007).

53. Ioannidis, J. P. Limitations are not properly acknowledged in the scientific literature. J. Clin. Epidemiol. 60, 324-329 (2007)

54. Pellizzon, Rd. F., Montero, E. Fd. S., Población, D. A., Monteiro, R. \& Castro, R. C. F. Brazilian scientific journals in surgery. III: analysis of the instructions for authors based on Vancouver uniform requirements. Acto Cirurgica Brasileira 22, 503-510 (2007).

55. Schneider, N., Lingner, H. \& Schwartz, F. W. Disclosing conflicts of interest in German publications concerning health services research. BMC Health Serv. Res. 7, 78 (2007).

56. Smidt, N., Overbeke, J., de Vet, H. \& Bossuyt, P. Endorsement of the STARD Statement by biomedical journals: survey of instructions for authors. Clin. Chem. 53, 1983-1985 (2007).

57. Wager, E. Do medical journals provide clear and consistent guidelines on authorship? Medscape General. Medicine 9, 16 (2007)

58. Axelin, A. \& Salanterä, S. Ethics in neonatal pain research. Nurs. Ethics 15, 492-499 (2008).

59. Casserly, M. F. \& Bird, J. E. Web Citation Availability. Libr. Resour. Tech. Serv 52, 42-53 (2008).

60. Freeman, S. R., Lundahl, K., Schilling, L. M., Jensen, J. D. \& Dellavalle, R. P. Human research review committee requirements in medical journals. Clin. Invest. Med. 31, E49-54 (2008).

61. Hopewell, S., Altman, D. G., Moher, D. \& Schulz, K. F. Endorsement of the CONSORT Statement by high impact factor medical journals: a survey of journal editors and journal 'Instructions to Authors'. Trials 9, 20 (2008).

62. Janosky, J. E. Statistical testing alone and estimation plus testing: Reporting study outcomes in biomedical journals. Stat. Probab. Lett. 78, 2327-2331 (2008).

63. Mrkobrada, M. et al. Need for quality improvement in renal systematic reviews. Clin. J. Am. Soc. Nephrol. 3, 1102-1114 (2008).

64. Perry, A. E. \& Johnson, M. Applying the Consolidated Standards of Reporting Trials (CONSORT) to studies of mental health provision for juvenile offenders: a research note. J. Exp. Criminol. 4, 165-185 (2008)

65. Piwowar, H. A. \& Chapman, W. W. (eds). A review of journal policies for sharing research data (ELPUB, 2008).

66. Salvagno, G. L., Lippi, G., Montagnana, M. \& Guidi, G. C. Standards of practice and uniformity in references style. Clin. Chem. Lab. Med. 46, 437-438 (2008).

67. Tharyan, P., Premkumar, T. S., Mathew, V. \& Barnabas, J. P. Editorial policy and the reporting of randomized controlled trials: a survey of instructions for authors and assessment of trial reports in Indian medical journals (2004-05). Natl. Med. J. India 21, 62-68 (2008).

68. Xu, L., Li, J., Zhang, M., Ai, C. \& Wang, L. Chinese authors do need CONSORT: reporting quality assessment for five leading Chinese medical journals. Contemp. Clin. trials 29, 727-731 (2008).

69. Bavdekar, S. B., Gogtay, N. J. \& Chavan, R. Reporting ethical processes: survey of 'instructions to authors' provided by Indian journals. Indian J. Med. Sci. 63, 260-262 (2009).

70. Blum, J. A., Freeman, K., Dart, R. C. \& Cooper, R. J. Requirements and definitions in conflict of interest policies of medical journals. JAMA 302, 2230-2234 (2009)

71. Monteiro, R., Brandau, R., Gomes, W. J. \& Braile, D. M. Trends in animal experimentation. Braz. J. Cardiovascular Surg. 24, 506-513 (2009).

72. Nchangwi, S. M., Asahngwa C. \& Chi P. C. Ethical considerations in instructions to authors of some journals published in Cameroon. Ebonyi Med. J. 8, 76-79 (2010).

73. Pengel, L. H., Barcena, L. \& Morris, P. J. The quality of reporting of randomized controlled trials in solid organ transplantation. Transpl. Int. 22, 377-384 (2009).

74. Pitak-Arnnop, P. et al. Reporting of ethical protection in recent oral and maxillofacial surgery research involving human subjects. Int. J. oral. Maxillofac. Surg. 38, 707-712 (2009).

75. Rowan-Legg, A., Weijer, C., Gao, J. \& Fernandez, C. A comparison of journal instructions regarding institutional review board approval and conflict-ofinterest disclosure between 1995 and 2005. J. Med. Ethics 35, 74-78 (2009).

76. Samad, A., Khanzada, T. W. \& Siddiqui, A. A. Do the instructions to authors of Pakistani medical journals convey adequate guidance for authorship criteria. Pak. J. Med. Sci. 25, 879-882 (2009).

77. Tavares-Neto, J. \& Azevêdo, E. S. Ethics relevance in Brazilian medical journals. Rev. da Assoç̧ão Médica Brasileira 55, 400-404 (2009). 
78. Akhabue, E. \& Lautenbach, E. "Equal" contributions and credit: an emerging trend in the characterization of authorship. Ann. Epidemiol. 20, 868-871 (2010).

79. Hooijmans, C. R., Leenaars, M. \& Ritskes-Hoitinga, M. A gold standard publication checklist to improve the quality of animal studies, to fully integrate the Three Rs, and to make systematic reviews more feasible. Alter. Lab. Anim. 38, 167-182 (2010).

80. Meerpohl, J. J., Wolff, R. F., Niemeyer, C. M., Antes, G. \& von Elm, E. Editorial policies of pediatric journals: survey of instructions for authors. Arch. Pediatrics Adolesc. Med. 164, 268-272 (2010).

81. Pitak-Arnnop, P. et al. Ethical issues in instructions to authors of journals in oral-craniomaxillofacial/facial plastic surgery and related specialities. $J$. Cranio-maxillo-facial Surg. 38, 554-559 (2010).

82. Ruiz-Pérez, R., Marcos-Cartagena, D., Delgado \& López-Cózar, E. Fulfilment of the criteria about scientific authorship in Spanish biomedical and health science journals included in Journal Citation Reports. Rev. Espanola de. Salud Publica 84, 809-825 (2010).

83. Alsheikh-Ali, A. A., Qureshi, W., Al-Mallah, M. H. \& Ioannidis, J. P. Public availability of published research data in high-impact journals. PLOS ONE 6, e24357 (2011).

84. Bennett, C. et al. Reporting guidelines for survey research: an analysis of published guidance and reporting practices. PLoS Med. 8, e1001069 (2011).

85. Bošnjak, L., Puljak, L., Vukojević, K. \& Marušić, A. Analysis of a number and type of publications that editors publish in their own journals: case study of scholarly journals in Croatia. Scientometrics 86, 227-233 (2011).

86. Fernandes, M. R., Queiroz, M. C. C. A. M., Moraes, M. R. D., Barbosa, M. A. \& Sousa, A. L. L. Ethical standards adopted by Brazilian journals of medical specialties. Rev. da Associação Médica Brasileira 57, 267-271 (2011).

87. Fleischhacker, S., Evenson, K. R., Singh, P., Rodriguez, D. A. \& Ammerman, A. Does this study inform policy: examination of leading childhood obesity journals' instructions to authors regarding policy-related research and implications. Childhood obesity: risk factors, health effects and prevention hauppauge. 135-52 (Nova Science Publishers, 2011).

88. Macrina, F. L. Teaching authorship and publication practices in the biomedical and life sciences. Sci. Eng. Ethics 17, 341-354 (2011).

89. Malafaia, G., Rodrigues, A. Sd. L. \& Talvani, A. Ethics in the publication of studies on human visceral leishmaniasis in Brazilian periodicals. Rev. de. Saude Publica 45, 166-172 (2011).

90. Meerpohl, J. J., Wolff, R. F., Antes, G. \& von Elm, E. Are pediatric open access journals promoting good publication practice? An analysis of author instructions. BMC Pediatrics 11, 27 (2011).

91. Miesle, L. M., Oblak, T. A., Shrode, L. D. \& Horton, A. M. (eds) Analyzing the landscape of author Instructions for general medicine journals: past and present. Curr. Med. Res. Opin. Informa Healthcare 1, S7 https:// www.ismpp.org/assets/docs/Education/AnnualMeeting/7thAM/ 2011_cmro_abstract_supplement.pdf (2011).

92. Moro, J. V., Rodrigues, J. S. M. \& Andre, S. C. S. Research involving human beings in instructions to authors in domestic scientific nursing magazines. Rev. Bioét (Impr.) 19, 543-552 (2011).

93. Navaneetha, C. Editorial policy in reporting ethical processes: a survey of 'instructions for authors' in International Indexed Dental Journals. Contemp. Clin. Dent. 2, 84 (2011).

94. Rands, S. A. Inclusion of policies on ethical standards in animal experiments in biomedical science journals. J. Am. Assoc. Lab. Anim. Sci. 50, 901-903 (2011).

95. Tao, K.-M. et al. From QUOROM to PRISMA: a survey of high-impact medical journals' instructions to authors and a review of systematic reviews in anesthesia literature. PLoS ONE 6, e27611 (2011)

96. Tao, T., Bo, L., Wang, F., Li, J. \& Deng, X. Equal contributions and credit given to authors in anesthesiology journals during a 10 -year period. Scientometrics 91, 1005-1010 (2011).

97. Yadav, P. \& Chavda, N. Survey of "instructions to authors" of Indian medical journals for reporting of ethics and authorship criteria. Indian J. Med. Ethics $\mathbf{8}$, 36 (2011).

98. Bošnjak, L. \& Marušić, A. Prescribed practices of authorship: review of codes of ethics from professional bodies and journal guidelines across disciplines. Scientometrics 93, 751-763 (2012).

99. Charlier, P. et al. Ethics requirements and impact factor. J. Med. ethics 38, 253-255 (2012).

100. Hopewell, S., Ravaud, P., Baron, G. \& Boutron, I. Effect of editors' implementation of CONSORT guidelines on the reporting of abstracts in high impact medical journals: interrupted time series analysis. BMJ 344, e4178 (2012).

101. Kunath, F. et al. Do journals publishing in the field of urology endorse reporting guidelines? A survey of author instructions. Urologia Int. 88, 54-59 (2012).

102. Li, X.-Q. et al. Endorsement of the CONSORT statement by high-impact medical journals in China: a survey of instructions for authors and published papers. PLoS ONE 7, e30683 (2012).
103. Shantikumar, S., Wigley, J., Hameed, W. \& Handa, A. A survey of instructions to authors in surgical journals on reporting by CONSORT and PRISMA. Ann. R. Coll. Surg. Engl. 94, 468-471 (2012).

104. Tulvatana, W., Thinkhamrop, B., Kulvichit, K. \& Tatsanavivat, P. Endorsement and implementation of high impact factor medical journals on the International Committee of Medical Journal Editors (ICMJE) policy of mandatory clinical trial registration. Asian Biomed. 6, 423-427 (2012).

105. Wang, F., Tang, L., Bo, L., Li, J. \& Deng, X. Equal contributions and credit given to authors in critical care medicine journals during a 10 -yr period. Crit. Care Med. 40, 967-969 (2012).

106. Borrego, Á. \& Garcia, F. (eds). Provision of supplementary materials in library and information science scholarly journals. Aslib Proceedings: New Information Perspectives (Emerald Group Publishing Limited, 2013).

107. Grant, S. P., Mayo-Wilson, E., Melendez-Torres, G. \& Montgomery, P. Reporting quality of social and psychological intervention trials: a systematic review of reporting guidelines and trial publications. PLOS ONE 8, e65442 (2013).

108. Malafaia, G., Guilhem, D. \& Talvani, A. Do Brazilian scientific journals promote the adherence of Chagas disease researchers to internacional ethical principals? Rev. do Inst. de. Med. Tropical de. São Paulo 55, 159-165 (2013).

109. Mathur, V., Dhillon, J., Kalra, G., Sharma, A. \& Mathur, R. Survey of instructions to authors in Indian and British Dental Journals with respect to ethical guidelines. J. Indian Soc. Pedodontics Prevent. Dent. 31, 107 (2013).

110. Panic, N., Leoncini, E., De Belvis, G., Ricciardi, W. \& Boccia, S. Evaluation of the endorsement of the preferred reporting items for systematic reviews and meta-analysis (PRISMA) statement on the quality of published systematic review and meta-analyses. PLoS ONE 8, e83138 (2013).

111. Reveiz, L., Villanueva, E., Iko, C. \& Simera, I. Compliance with clinical trial registration and reporting guidelines by Latin American and Caribbean journals. Cad. de. Saude Publica 29, 1095-1100 (2013).

112. Salamat, F., Sobhani, A.-R. \& Mallaei, M. Quality of publication ethics in the instructions to the authors of Iranian journals of medical sciences. Iran. J. Med. Sci. 38, 57 (2013).

113. Santos, S. M. D. \& Noronha, D. P. Brazilian scientific journals in Social Sciences and Humanities indexed by SciELO database: formal aspects. Perspect. em Ciência da Inf.ção 18, 2-16 (2013).

114. Teixeira, R. K. C., Yamaki, V. N., Gonçalves, T. B., Botelho, N. M. \& Silva, J. A. Cd. Does impact factor influence the ethics of the instructions provided to journal authors? Rev. da Assoc.ção Médica Brasileira 59, 280-284 (2013).

115. Tharyan, P., George, A. T., Kirubakaran, R. \& Barnabas, J. P. Reporting of methods was better in the Clinical Trials Registry-India than in Indian journal publications. J. Clin. Epidemiol. 66, 10-22 (2013).

116. Yoshida, A., Dowa, Y., Murakami, H. \& Kosugi, S. Obtaining subjects' consent to publish identifying personal information: current practices and identifying potential issues. BMC Med. Ethics 14, 47 (2013).

117. Aleixandre-Benavent, R. et al. Public availability of published research data in substance abuse journals. Int. J. Drug Policy 25, 1143-1146 (2014).

118. Betini, M., Volpato, E. S., Anastácio, G. D., Faria, R. T. \& El Dib, R. Choosing the right journal for your systematic review. J. evaluation Clin. Pract. 20, 834-836 (2014).

119. Broga, M., Mijaljica, G., Waligora, M., Keis, A. \& Marusic, A. Publication ethics in biomedical journals from countries in Central and Eastern Europe. Sci. Eng. Ethics 20, 99-109 (2014).

120. Choi, J., Jun, J. H., Kang, B. K., Kim, K. H. \& Lee, M. S. Endorsement for improving the quality of reports on randomized controlled trials of traditional medicine journals in Korea: a systematic review. Trials 15, 429 (2014).

121. Courbon, Ė., Tanguay, C., Lebel, D. \& Bussières, J.-F. Paternité des articles et intérêts concurrents: une analyse des recommandations aux auteurs des journaux traitant de pratique pharmaceutique. Can. J. hospital Pharm. 67, 188 (2014).

122. Fuller, T., Peters, J., Pearson, M. \& Anderson, R. Impact of the transparent reporting of evaluations with nonrandomized designs reporting guideline: ten years on. Am. J. public health 104, e110-7 (2014).

123. Gasparyan, A. Y., Ayvazyan, L., Gorin, S. V. \& Kitas, G. D. Upgrading instructions for authors of scholarly journals. Croatian Med. J. 55, 271 (2014).

124. Grgić, I. H. (ed.) IL and information ethics: how to avoid plagiarism in scientific papers? European Conference on Information Literacy (Springer, 2014).

125. Hoffmann, T., English, T. \& Glasziou, P. Reporting of interventions in randomised trials: an audit of journal instructions to authors. Trials 15, 20 (2014).

126. Hooft, L., Korevaar, D., Molenaar, N., Bossuyt, P. \& Scholten, R. Endorsement of ICMJE's Clinical Trial Registration Policy: a survey among journal editors. Neth J. Med. 72, 349-355 (2014).

127. Nguyen, J. T., Shahid, R. \& Manera, R. Pediatric case reports: assessing recommendations from journals' instructions to authors. Hosp. Pediatr. 4, 39-43 (2014). 
128. Sankar, P., Cho, M. K., Monahan, K. \& Nowak, K. Reporting race and ethnicity in genetics research: do journal recommendations or resources matter? Sci. Eng. ethics 21, 1353-1366 (2014).

129. Splendiani, B. \& Ribera, M. Accessible images in computer science journals. Procedia Computer Sci. 27, 9-18 (2014).

130. Splendiani, B., Ribera, M., Garcia, R. \& Termens, M. Do physicians make their articles readable for their blind or low-vision patients? An analysis of current image processing practices in biomedical journals from the point of view of accessibility. J. Digital Imaging 27, 419-442 (2014).

131. Valles, E. G. \& Bernacchi, A. S. Do Latin American scientific journals follow dual-use review policies? Biosecurity Bioterrorism: Biodefense Strategy Pract. Sci. 12, 94-105 (2014)

132. Xiao, L., Hu, J., Zhang, L. \& Shang, H.-C. Endorsement of CONSORT by Chinese medical journals: a survey of "instruction to authors". Chin. J. Integr. Med. 20, 510-515 (2014).

133. Aleixandre-Benavent, R. et al (eds) Open availability of articles and raw research data in spanish pediatrics journals. An Pediatr. (Barc.) 82, e90-4 (2015).

134. Barać, L. Definitions and Research of Authorship Across Various Scholarly Disciplines. Doctoral thesis. Zadar: University of Zadar (2015).

135. Glujovsky, D. et al. Quality of reporting in infertility journals. Fertil. Steril. 103, 236-241 (2015).

136. Hartemink, A. E. The use of soil classification in journal papers between 1975 and 2014. Geoderma Regional 5, 127-139 (2015).

137. Horvat, M., Mlinaric, A., Omazic, J. \& Supak-Smolcic, V. An analysis of medical laboratory technology journals' instructions for authors. Sci. Eng. ethics 22, 1095-1106 (2015).

138. Koch, M., Riss, P., Kölbl, H., Umek, W. \& Hanzal, E. Disclosures, conflict of interest, and funding issues in urogynecology articles: a bibliometric study. Int. Urogynecol. J. 26, 1503-1507 (2015).

139. Probst, P. et al. Thirty years of disclosure of conflict of interest in surgery journals. Surgery 157, 627-633 (2015).

140. Roig, F. \& Borrego, A. Conflict of interest disclosure policies in clinically oriented Spanish biomedical journals. Revista Española de Documentación Científica. 38, 1-15 (2015).

141. Smith, T. A. et al. Do surgery journals insist on reporting by CONSORT and PRISMA? A follow-up survey of 'instructions to authors'. Ann. Med. Surg. 4, 17-21 (2015).

142. Song, T.-J., Leng, H.-F., Zhong, L. L., Wu, T.-X. \& Bian, Z.-X. CONSORT in China: past development and future direction. Trials 16, 243 (2015).

143. Stojanovski, J. Do Croatian open access journals support ethical research? Content analysis of instructions to authors. Biochemia Med.: Biochemia Med. 25, 12-21 (2015).

144. Stojanovski, J. editor Journals' Editorial Policies-an analysis of the instructions for authors of Croatian Open Access Journals. The International Conference on Electronic Publishing (Elpub) (IOS Press BV, Valetta, Malta, 2015).

145. Teixeira, R. K., Yamaki, V. N., Pontes, R. V., Brito, M. V. \& da Silva, J. A. Evaluation of ethical in instructions to authors of brazilian surgical journals. Arq. Bras. Cir. Dig. 28, 247-249 (2015).

146. Tierney, E., O'Rourke, C. \& Fenton, J. What is the role of 'the letter to the editor'? Eur. Arch. Oto-Rhino-Laryngol. 272, 2089-2093 (2015).

147. Yang, W. \& Zou, Q. The ethical issues in instructions for authors of Chinese biomedical journals. Learn Publ. 28, 216-222 (2015).

148. da Silva, J. A. T. In defense of the use of italic for latin binomial plant names. Polish Botan. J. 61, 1-6 (2016).

149. Hernández-Ruiz, A. Antifraud Editorial Policy in Spanish and Latin American Scientific Publication: JCR Social Sciences Edition/La política editorial antifraude de las revistas científicas españolas e iberoamericanas del JCR en Ciencias Sociales. Comun. (Engl. Ed.) 24, 19-27 (2016).

150. Hua, F., Walsh, T., Glenny, A.-M. \& Worthington, H. Surveys on reporting guideline usage in dental journals. J. Dent. Res. 95, 1207-1213 (2016).

151. Janakiram, C. \& Porteri, C. Ethical process reporting in Indian dental journals. Account. Res. 23, 163-177 (2016)

152. Jia, Z. et al. Equal contributions and credit: an emerging trend in the characterization of authorship in major spine journals during a 10-year period. Eur. Spine J. 25, 913-917 (2016).

153. Koch, M., Riss, P., Umek, W. \& Hanzal, E. The explicit mentioning of reporting guidelines in urogynecology journals in 2013: a bibliometric study. Neurourol. Urodyn. 35, 412-416 (2016).

154. Koch, M., Riss, P., Umek, W. \& Hanzal, E. CONSORT and the internal validity of randomized controlled trials in female pelvic medicine. Neurourol. Urodyn. 35, 826-830 (2016).

155. Lei, S.-Y., Dong, Y.-P., Zhu, W.-F. \& Li, L.-J. An emerging trend of equal authorship credit in major public health journals. SpringerPlus 5, 1083 (2016).

156. Liu, T.-Y. et al. The content of statistical requirements for authors in biomedical research journals. Chin. Med. J. 129, 2491 (2016).
157. Ma, B. et al. Endorsement of the CONSORT statement by Chinese journals of Traditional Chinese Medicine: a survey of journal editors and review of journals' instructions for authors. Acupunct. Med. 34, 178-183 (2016).

158. Mishra, A. K., Parmar, A., Kaloiya, G. S. \& Balhara, Y. P. S. (eds) A descriptive analysis of instructions to authors for statistical reporting of article in addiction medicine journals. Indian J. Psychiatry ANCIPS 58, S69 (2016).

159. Nedovic, D., Panic, N., Pastorino, R., Ricciardi, W. \& Boccia, S. Evaluation of the endorsement of the STrengthening the REporting of Genetic Association studies (STREGA) statement on the reporting quality of published genetic association studies. J. Epidemiol. 26, 399-404 (2016).

160. Pouwels, K. B., Widyakusuma, N. N., Groenwold, R. H. \& Hak, E. Quality of reporting of confounding remained suboptimal after the STROBE guideline. $J$ Clin. Epidemiol. 69, 217-224 (2016).

161. Roberts, E. A., Troiano, C. \& Spiegel, J. H. Standardization of guidelines for patient photograph deidentification. Ann. Plast. Surg. 76, 611-614 (2016).

162. Shamseer, L., Hopewell, S., Altman, D. G., Moher, D. \& Schulz, K. F. Update on the endorsement of CONSORT by high impact factor journals: a survey of journal "Instructions to Authors" in 2014. Trials 17, 301 (2016).

163. Sims, M. T., Henning, N. M., Wayant, C. C. \& Vassar, M. Do emergency medicine journals promote trial registration and adherence to reporting guidelines? A survey of "Instructions for Authors". Scand. J. Trauma, Resuscitation Emerg. Med. 24, 137 (2016).

164. Vetter, D., Storch, I. \& Bissonette, J. A. Advancing landscape ecology as a science: the need for consistent reporting guidelines. Landsc. Ecol. 31, 469-479 (2016).

165. Bhat, A., Shah, A. \& Sherighar, S. G. Instructions to prospective authors by Indian biomedical journals: An opportunity to promote responsible conduct of research. J. Empir. Res. Hum. Res. Ethics 12, 117-123 (2017).

166. Bolshete, P. Authorship criteria and reporting of ethical compliance in Indian biomedical journals. Indian J. Med. ethics 2, 160-164 (2017).

167. Martin, G. \& Clarke, R. M. Are psychology journals anti-replication? A snapshot of editorial practices. Front. Psychol. 8, 523 (2017).

168. Mercieca-Bebber, R. et al. Preliminary evidence on the uptake, use and benefits of the CONSORT-PRO extension. Qual. Life Res. 26, 1427-1437 (2017).

169. Pieper, D. \& Mathes, T. Survey of instructions for authors on how to report an update of a systematic review: guidance is needed. Evid.-Based Med. 22, 45-48 (2017).

170. Shamseer, L. et al. Potential predatory and legitimate biomedical journals: can you tell the difference? A cross-sectional comparison. BMC Med. 15, 28 (2017).

171. Tam, W. W., Lo, K. K. \& Khalechelvam, P. Endorsement of PRISMA statement and quality of systematic reviews and meta-analyses published in nursing journals: a cross-sectional study. BMJ open 7, e013905 (2017).

172. Taquette, S. R. \& Villela, W. V. Knowledge references: analysis of Brazilian health journal instructions to authors. Cienc. Saude Coletiva 22, 7-13 (2017).

173. Wayant, C., Smith, C., Sims, M. \& Vassar, M. Hematology journals do not sufficiently adhere to reporting guidelines: a systematic review. J. Thrombosis Haemost. 15, 608-617 (2017).

174. Malički, M., ter Riet, G., Bouter, L. M. \& Aalbersberg, I. J. J. Project: Fostering Transparent and Responsible Conduct of Research: What can Journals do?: Mendeley Data; 2019. https://doi.org/10.17632/53cskwwpdn.5.

175. Marušić, A. et al. Editorial research and the publication process in biomedicine and health: Report from the Esteve Foundation Discussion Group, December 2012. Biochemia Med. 24, 211-216 (2014).

176. Marusic, A., Katavic, V. \& Marusic, M. Role of editors and journals in detecting and preventing scientific misconduct: strengths, weaknesses, opportunities, and threats. Med. law 26, 545-566 (2007).

177. Ioannidis, J. P. A., Fanelli, D., Dunne, D. D. \& Goodman, S. N. Meta-research: Evaluation and Improvement of Research Methods and Practices. PLOS Biol. 13, e1002264 (2015)

178. Blanco, D. et al. Interventions to improve adherence to reporting guidelines in health research: a scoping review protocol. BMJ open 7, e017551 (2017).

179. Wieman, C. \& Gilbert, S. Taking a scientific approach to science education. Part I-Res. Microbe 10, 152-156 (2015).

180. Blanco, D. et al. Scoping review on interventions to improve adherence to reporting guidelines in health research. BMJ open 9, e026589 (2019).

181. Moreno J. D. Ethics committees and ethics consultants. A companion to bioethics. Malden: Wiley-Blackwell. 475-84 (2009).

182. Allison, D. B., Brown, A. W., George, B. J. \& Kaiser, K. A. Reproducibility: a tragedy of errors. Nature 530, 27-29 (2016).

183. Gotzsche, P. Why we need easy access to all data from all clinical trials and how to accomplish it. Trials 12, 249 (2011).

184. Glasziou, P. et al. Reducing waste from incomplete or unusable reports of biomedical research. Lancet 383, 267-276 (2014).

185. SHERPA RoMEO 2020. Available from: https://v2.sherpa.ac.uk/romeo/.

186. Platform for Responsible Editorial Policies (PREP) [Internet]. Radboud University's Institute for Science in Society and Leiden University's Centre for 
Science and Technology Studies: ZonMw PREP Project; 2020. Available from: https://www.responsiblejournals.org/.

187. Mellor D. New Measure Rates Quality of Research Journals' Policies to Promote Transparency and Reproducibility [Internet]. Charlottesville (VA): Center for Open Science; 2020. Available from: https://www.cos.io/about/ news/new-measure-rates-quality-research-journals-policies-promotetransparency-and-reproducibility.

188. Goldacre, B. et al. Compliance with requirement to report results on the EU Clinical Trials Register: cohort study and web resource. BMJ 362, k3218 (2018).

189. Marušić, A., Sambunjak, D. \& Marušić, M. Journal quality and visibility: is there a way out of the scientific periphery? Contributions/Macedonian Academy of Sciences and Arts. Sect. Biol. Med. Sci. 27, 151-161 (2006).

190. Karlawish, J. H., Hougham, G. W., Stocking, C. B. \& Sachs, G. A. What is the quality of the reporting of research ethics in publications of nursing home research? J. Am. Geriatrics Soc. 47, 76-81 (1999).

191. Korevaar, D. Increasing Value in Diagnostic Research: Publication and Reporting of Test Accuracy Studies (University of Amsterdam, 2016).

192. Goldacre, B. et al. COMPare: a prospective cohort study correcting and monitoring 58 misreported trials in real time. Trials 20, 118 (2019).

193. Moher, D., Liberati, A., Tetzlaff, J., Altman, D. G. \& Group, P. Preferred reporting items for systematic reviews and meta-analyses: the PRISMA statement. PLoS Med. 6, e1000097 (2009).

194. Ouzzani, M., Hammady, H., Fedorowicz, Z. \& Elmagarmid, A. Rayyan-a web and mobile app for systematic reviews. Syst. Rev. 5, 210 (2016).

195. Guolo, A. \& Varin, C. Random-effects meta-analysis: the number of studies matters. Stat. Methods Med. Res. 26, 1500-1518 (2017).

196. Finch, S. \& Cumming, G. Putting research in context: understanding confidence intervals from one or more studies. J. Pediatr. Psychol. 34, 903-916 (2009).

\section{Acknowledgements}

We would like to thank Ana Utrobičić for her help with developing the search strategy. We would like to thank Anna Tordai for help with data extraction and translation of articles in Hungarian and French, Sjors de Heuvel for an article in Japanese, Lionel Dias for articles in Spanish and Portuguese, Yong Hu for an article in Chinese, and Natalia Lee for an article in Korean. Finally, we would like to thank Bianca Kramer for her help in search strategies to extract number of publications in Crossref, PubMed, Scopus, and Web of Science. This study was a part of the Elsevier funded project Fostering Transparent and Responsible Conduct of Research: What can Journals do? The work of AJ was supported by the Croatian National Science Foundation (HRZZ IP-2018-01-4729).

\section{Author contributions}

M.M.: conceptualisation, data curation, formal analysis, investigation, methodology, visualisation, writing — original draft preparation, writing_review \& editing., A.J.: conceptualization, data curation, formal analysis, investigation, methodology, visualisation, writing—original draft preparation, writing—review \& editing, I.J.J.A.: conceptualization, methodology, funding acquisition, writing-review \& editing, L.B.: conceptualization, methodology, funding acquisition, writing — review \& editing, G.t.R.: conceptualization, methodology, project administration, supervision, writing_-review \& editing.

\section{Competing interests}

I.J.J.A. is Senior Vice-President of Research Integrity for Elsevier. M.M. is a Co-Editor-inChief of BMC's Research Integrity and Peer Review journal. G.t.R. was an author of one study included in this review ${ }^{49}$, however the inclusion of the study in the review, as well as data extraction and analysis were conducted by M.M. and A.J. The remaining authors declare no competing interests.

\section{Additional information}

Supplementary information The online version contains supplementary material available at https://doi.org/10.1038/s41467-021-26027-y.

Correspondence and requests for materials should be addressed to Mario Malički.

Peer review information Nature Communications thanks Arindam Basu, Helen Buckley Woods, and Holy Grossetta Nardini for their contribution to the peer review of this work. Peer reviewer reports are available.

Reprints and permission information is available at http://www.nature.com/reprints

Publisher's note Springer Nature remains neutral with regard to jurisdictional claims in published maps and institutional affiliations.

(c) (i) Open Access This article is licensed under a Creative Commons Attribution 4.0 International License, which permits use, sharing, adaptation, distribution and reproduction in any medium or format, as long as you give appropriate credit to the original author(s) and the source, provide a link to the Creative Commons license, and indicate if changes were made. The images or other third party material in this article are included in the article's Creative Commons license, unless indicated otherwise in a credit line to the material. If material is not included in the article's Creative Commons license and your intended use is not permitted by statutory regulation or exceeds the permitted use, you will need to obtain permission directly from the copyright holder. To view a copy of this license, visit http://creativecommons.org/ licenses/by/4.0/.

(C) The Author(s) 2021 